\title{
Polyphenols from grape pomace induce osteogenic differentiation in mesenchymal stem cells
}

\author{
ELISA TORRE $^{1}$, GIORGIO IVIGLIA $^{1}$, CLARA CASSINELLI $^{1}$, MARCO MORRA $^{1}$ and NAZARIO RUSSO ${ }^{2}$ \\ ${ }^{1}$ Nobil Bio Ricerche srl, I-14037 Portacomaro; ${ }^{2}$ University of Cagliari, \\ European Institute of Medical Studies-Universidade Fernando Pessoa, Specialization School, I-09124 Cagliari, Italy
}

Received September 6, 2019; Accepted February 19, 2020

DOI: $10.3892 /$ ijmm.2020.4556

\begin{abstract}
Polyphenols are increasingly investigated for the treatment of periodontitis and research on their use in dental biomaterials is currently being conducted. Grape pomace extracts are a rich source of polyphenols. In the present study, the polyphenols of two different types of grape pomace were characterized and identified by high-performance liquid chromatography-diode array detector, and the effect of polyphenol-rich grape pomace extracts on mesenchymal stem cell (MSC) osteogenic differentiation was investigated. Solid-liquid extraction was used to recover polyphenols from red and white grape pomace. The two extracts have been characterized through the phenolic content and antioxidant power. Human MSCs (hMSCs) from the bone marrow were cultured both with and without given amounts $(10$ or $20 \mu \mathrm{g} / \mathrm{ml})$ of the obtained pomace extracts. Their effects on cell differentiation were evaluated by reverse transcription-quantitative polymerase chain reaction, compared with relevant controls. Results showed that both pomace extracts, albeit different in phenolic composition and concentration, induced multiple effects on hMSC gene expression, such as a decreased receptor
\end{abstract}

Correspondence to: Dr Elisa Torre, Nobil Bio Ricerche srl, via Valcastellana 26, I-14037 Portacomaro, Italy

E-mail: etorre@nobilbio.it

Abbreviations: Colla1, a 1 type 1 collagen; BMP2, bone morphogenetic protein 2; DPPH, 2,2-diphenyl-1-picrylhydrazyl; FC, folin-Ciocalteu method; GAE, gallic acid equivalents; HPLC, high-performance liquid chromatography; hMSCs, human mesenchymal cells; iBSP, integrin-binding sialoprotein; MMPs, metalloproteinases; OCN, osteocalcin; OPG, osteoprotegerin; PRPEs, polyphenol-rich pomace extracts; RT-qPCR, reverse transcription-quantitative polymerase chain reaction; RANKL, receptor activator of nuclear factor $\kappa$-B ligand; Runx2, runt-related transcription factor 2; SPARC, secreted protein acidic and cysteine rich; TIMPs, tissue inhibitor of metalloproteinases; YWHAZ, tyrosine 3-monooxygenase/tryptophan 5-monooxygenase activation protein $\zeta$

Key words: polyphenols, mesenchymal cells, pomace extract, bone regeneration, dental materials activator of nuclear factor $\kappa$-B ligand/osteoprotegerin ratio and an enhanced expression of genes involved in osteoblast differentiation, thus suggesting a shift of hMSCs towards osteoblast differentiation. The obtained results provided data in favor of the exploitation of polyphenol properties from grape pomace extracts as complementary active molecules for dental materials and devices for bone regeneration in periodontal defects.

\section{Introduction}

The regenerative potential of polyphenols is attracting increasing attention in the field of oral health, thanks to their anti-inflammatory and anti-oxidant properties ascribed to their molecular structure. Flavonoids, a major subclass of polyphenols, have an anti-inflammatory action and are capable of modulating the host inflammatory response $(1,2)$. Clinical evidence has shown that flavonoids have beneficial effects on periodontitis $(1,3)$, an oral inflammatory disease of polymicrobial origin that causes the destruction of gingival connective tissue and the alveolar bone supporting the teeth. Periodontitis affects $30 \%$ of adults (4). Cell biology and in vivo rodent model studies (5-7) have revealed a multiplicity of effects exerted by flavonoids on periodontal cells and tissues, including the regulation of the inflammatory response in periodontal components, and potential preserving effects on periodontal ligaments and alveolar bone tissues (8). Potentially beneficial effects of flavonoids have been reported in various periodontal cells, as well as alveolar bone-maintaining osteoblasts. Proanthocyanidins have been shown to exert protective effects against oxidative stress and periodontitis, both in vitro and in vivo $(9,10)$. Multiple study findings have shown that polyphenols can counteract the shift towards osteoclastogenesis in bone-loss pathologies (11-14).

In addition to the role played by the molecular structure of polyphenols in controlling inflammation and related tissue-protection mechanisms, mounting evidence has suggested their active involvement in tissue formation. With regards to, for example, bone tissue, it has been shown that polyphenols exert effects on osteoblasts by involving different signaling pathways, such as Wingless-INT/ $\beta$-catenin (15), insulin-like growth factor (16), bone morphogenetic proteins (17), Runt-related transcription factor 2 (Runx2) (18) and Osterix (19). Furthermore, due to a structural similarity to 
mammalian estrogens, some polyphenols, such as isoflavones, are also called phytoestrogens and are able to bind to estrogen receptors (ERs) $\alpha$ and $\beta$, thus acting as hormone analogs with different agonistic or antagonistic actions, depending on the tissue (20). The role of polyphenols in different mechanisms of bone formation has recently been reviewed $(21,22)$.

These aforementioned properties make polyphenol molecules of particular interest to dental materials and devices. Presently in oral surgery, most dental biomaterials, including bone fillers, work through a simple scaffolding effect, providing osteoconduction (i.e., adhesion and growth of osteogenic cells, but no direct osteoinduction, such as triggering of mechanisms of new bone formation) (23). In a clinical setting, dental implants stimulate new bone formation through a physical effect, namely through a controlled surface roughness (24). The emerging field of biomolecular modifications of bone implants and dental biomaterials aims at enhancing the host tissue response through biologically active molecules delivered from the device or linked to the device surface (25-29). The biomolecular modification of dental devices and materials through polyphenols from different sources is being investigated (30-38).

A key-issue in the exploitation of polyphenol properties is their source. Polyphenol-rich pomace extracts (PRPEs), obtained through straightforward solid-liquid extraction (39-41), are of particular interest, due to availability, as well as economical and ethical reasons. The heterogeneity of the mixture makes these extracts extremely interesting, since it is possible to take advantage of the potential of a large number of polyphenolic classes.

The aim of the present study was to investigate the effects of 2 PRPEs, very different in terms of molecular composition and content, on hMSC osteogenic commitment. The first PRPE is obtained from Croatina, a red grape variety very rich in proanthocyanidins, whereas the second one is obtained from Arneis, a white grape characterized by the absence of proanthocyanidins and richness in phenolic acids. Red grapes notoriously contain a greater amount of polyphenols than white ones (42-44). However, in the making of Arneis wine (white wine making), once grapes are pressed, skins are removed in order to obtain a juice fermented without skin contact. Hence, skin polyphenols are not extracted and remain in the pomace. Conversely, the making of wine from Croatina (red wine making) involves the fermentation of pulp together with the grape skins, which give wine its typical color through the extraction of a fraction of the polyphenols they contain, rendering the pomace partially deprived of skin polyphenols.

In particular, it was demonstrated that, through specific classes of phenolic compounds identified in the 2 grape-pomace extracts, it is possible to induce a specific biomolecular response in human MSCs (hMSCs). The present study aimed at setting the basis for conscious design of bone implant dental devices and materials through biomolecular modification involving specific PRPEs, obtained from winery byproducts and, specifically, from the Croatina and Arneis varieties. This aspect represents the novelty of this study, in fact the use of an original complex mixture of polyphenols was shown to induce the same results of osteogenic differentiation in MSCs elicited by single phenolic standards or a mixture of them (45-50).

\section{Materials and methods}

Standards and chemicals. All chemicals were analytical-reagent grade and the water was distilled prior to use (Milli-Q Adavantage A10; EMD Millipore). Chemicals, including acetone, acetic acid, hydrochloric acid, Folin-Ciocalteu (FC) reagent, 2,2-diphenyl-1-picrylhydrazyl (DPPH), sodium carbonate, sodium bisulphite, gallic acid (GA), quercetin, rutin, caffeic acid, p-coumaric acid and malvidin-3-glucoside, were all purchased from Merck KGaA. Grape pomace was purchased from local winery producers; red grape (Croatina) from Alemat (Ponzano Monferrato) and white grape (Arneis) from Tenuta Carretta (Piobesi d'Alba).

PRPE. Grape pomace was collected and stored at $-20^{\circ} \mathrm{C}$ under vacuum until the beginning of the extraction process. A multiresidual control was performed on both PRPEs following the UNI EN 15662:2009 methods, to avoid any collateral effect on cells due to possible residual pesticides. Prior to extraction, they were washed with acidified water, dried in a circulating-air oven $\left(37^{\circ} \mathrm{C} \pm 5^{\circ} \mathrm{C}\right.$-UN260; Memmert $\left.\mathrm{GmbH}+\mathrm{Co} . \mathrm{KG}\right)$ and grinded in a bladed mill (GM 200; Retsch $\mathrm{GmbH}$ ). The milled grape pomace $(300 \mathrm{~g})$ was extracted from $2,000 \mathrm{ml}$ of $50: 50$ acetone:water ( $\mathrm{v} / \mathrm{v})$ using an automatic extractor (TIMATIC Micro C, Tecnolab). The extraction cycle is fully automatic and alternates a dynamic phase, obtained in programmed pressure, and a static phase, in which a forced percolation is generated, thus ensuring a continuous solvent flow to the interior of the plant matrix and avoiding oversaturation, thanks to the programmable recirculation.

Next, the obtained solution was concentrated in a rotavap (Laborota 4001) under reduced pressure (and maintained in the fridge between $2-4^{\circ} \mathrm{C}$ ).

In the present study, two different PRPEs were prepared: One from white (Arneis) and the other from red (Croatina) grape pomace. After the total phenolic content measurements were obtained, PRPEs were diluted in water to reach a common concentration of $1 \mathrm{mg} / \mathrm{ml} \mathrm{GA}$ equivalents (GAE).

High-performance liquid chromatography (HPLC) coupled with diode array detector (DAD). PRPEs from Arneis and Croatina have been characterized using HPLC Shimadzu LC 2010 AHT equipped with Shimadzu SPD-M10AVP DAD. PRPEs were filtered using $0.2 \mu \mathrm{m}$ cellulose acetate filters and analyzed using a C8 Luna column (150x4.6 mm; $5 \mu \mathrm{m}$ particle size) from Phenomenex operated at $25^{\circ} \mathrm{C}$. The mobile phase consisted of $2 \%(\mathrm{v} / \mathrm{v})$ acetic acid in water (mobile phase A) and $0.5 \%$ acetic acid in water and acetonitrile (50:50 v/v) (mobile phase B). The gradient program shown in Table I was used, at a flow rate of $0.8 \mathrm{ml} / \mathrm{min}$ and a total running time of $123 \mathrm{~min}$ (51). The injection volume was $10 \mu \mathrm{l}$ and the DA recorded spectra at $200-600 \mathrm{~nm}$. The quantification of individual polyphenols was performed using calibration curves of the corresponding reference compounds. GA $(280 \mathrm{~nm})$, quercetin $(370 \mathrm{~nm})$, rutin $(355 \mathrm{~nm})$, caffeic acid $(320 \mathrm{~nm}), \mathrm{p}$-coumaric acid $(370 \mathrm{~nm})$ and malvidin-3-glucoside $(520 \mathrm{~nm})$ were dissolved in an ethanol/water solution at concentrations of 1, 5, 10, 50100 , 150 and $200 \mu \mathrm{g} / \mathrm{ml}$ and analyzed using the aforementioned HPLC method. The quantification was performed by applying the standard calibration curve. 
Table I. High pressure liquid chromatography gradient method for separation of polyphenols in polyphenol-rich pomace extracts of Arneis and Croatina.

\begin{tabular}{lcc}
\hline Time (min) & MPA $(\%)$ & MPB $(\%)$ \\
\hline $0-35$ & $100 \rightarrow 95$ & $0 \rightarrow 5$ \\
$35-80$ & $95 \rightarrow 80$ & $5 \rightarrow 20$ \\
$80-110$ & $80 \rightarrow 0$ & $20 \rightarrow 100$ \\
$110-113$ & 0 & 100 \\
$113-123$ & $0 \rightarrow 100$ & $100 \rightarrow 0$ \\
\hline
\end{tabular}

MPA, mobile phase A; MBP, mobile phase B.

Phenolic content. The initial phenolic content of Arneis and Croatina PRPEs was evaluated using the FC method. All extracts were transferred into a 25-ml volumetric flask and diluted with distilled water at a ratio of 1:50. Subsequently, $0.5 \mathrm{~g} \mathrm{FC}$ reagent was added and mixed for $5 \mathrm{~min}$, and then $1.5 \mathrm{~g}$ of $20 \%$ anhydrous sodium carbonate (w/v) solution was added. After $2 \mathrm{~h}$, the absorbance was measured at $765 \mathrm{~nm}$, using water as the compensation liquid and a quartz cell (10-mm path length) in a UV-Vis spectrophotometer (T80+, PG Instruments Limited). The absorbance value was used to calculate the concentration of polyphenols using a calibration curve obtained with GA. The results are expressed as $\mathrm{mg} / \mathrm{ml}$ of GAE, which means the amount of gallic acid needed to have the same polyphenolic concentration of the extract.

Calibration curve: A total of $10 \mathrm{mg}$ GA was diluted in $10 \mathrm{ml}$ water to obtain $1 \mathrm{mg} / \mathrm{ml}$ stock solution. Aliquots of stock solution were transferred into a $25-\mathrm{ml}$ volumetric flask and diluted in water at the final concentrations of $0.05,0.025,0.01$ and $0.005 \mathrm{mg} / \mathrm{ml}$. Each standard solution was prepared according to the procedure described above for the PRPEs; the absorbance was measured under the same condition as for PRPEs.

This method was used to calculate the initial phenolic content and the amount of water needed to dilute the PRPE at a concentration of $1 \mathrm{mg} / \mathrm{ml}$.

Antioxidant power. The ability of water PRPEs $(1 \mathrm{mg} / \mathrm{ml}$ of GAE) to scavenge the DPPH radical was estimated using the method described by Brand-Williams et al (52). An aliquot of $40 \mu \mathrm{l}$ PRPEs was added to 1,600 $\mu 1$ water:ethanol 50:50 (v/v) solution. Separately, a DPPH solution $(0.1 \mathrm{mg} / \mathrm{ml} \mathrm{w} / \mathrm{v})$ was prepared in ethanol and $2 \mathrm{ml}$ of this solution was added to the reaction mixture. Next, the solution was well-shaken and incubated for $30 \mathrm{~min}$ at room temperature in the dark and absorbance was recorded at $525 \mathrm{~nm}$. The blank solution was made up by a solution of water:ethanol instead of PRPE. The percentage inhibition of the DPPH radical by the samples was calculated using the following equation:

$$
\% \text { Reduction }=\left(\frac{A_{0}-A_{1}}{A_{0}}\right) \times 100 \text { eq. } 1
$$

Where $A_{0}$ is the absorbance of control sample and $A_{1}$ is the absorbance of the test sample. The reduction of the absorbance was used as value to indicate the antioxidant power.
Determination of anthocyanins. The methods of Ribéreau-Gayon and Stonestreet have been widely used to determine the concentration of proanthocyanidins in red wine (53). The determination of anthocyanins of the grape pomace is carried out using two properties stemming from their molecular features: The modification of their colors according to the $\mathrm{pH}$ and the transformation into colorless derivatives under the action of certain reagents, such as bisulphite ions. Thus, the variation of the absorbance read at $520 \mathrm{~nm}$ following the addition of excess bisulphite ions is proportional to the anthocyanin content.

Briefly, solution A was prepared in a test tube of $50 \mathrm{ml}$, as follows: Mix $1 \mathrm{ml}$ of PRPE with $1 \mathrm{ml}$ of acidified ethanol solution [0.1\% v/v hydrocholoric acid $(\mathrm{HCl})]$ and $20 \mathrm{ml} \mathrm{HCl}$ solution (2\% of $\mathrm{HCl}$ in distilled water). Subsequently, $5 \mathrm{ml}$ solution A was mixed in a 25-ml test tube with $2 \mathrm{ml}$ distilled water (solution B); furthermore, $5 \mathrm{ml}$ solution A was mixed with $2 \mathrm{ml}$ sodium bisulfite solution in another 25-ml test tube (concentration of $150 \mathrm{~g} / \mathrm{l}$; solution C).

Using an UV-Vis spectrophotometer, absorbance at $520 \mathrm{~nm}$ was recorded for both solutions $\mathrm{B}$ and $\mathrm{C}$, and the absorbance variation was used to calculate the amount of anthocyanins contained in the PRPE. Quantification has been made using a calibration curve made through the standard anthocyanin malvidin-3-glucoside dissolved in an ethanol/water solution at concentrations of 1, 5, 10, 20, 50, 100, 200, 300 and $500 \mu \mathrm{g} / \mathrm{ml}$. Malvidin-3-glucoside solutions have been analyzed using the aforementioned method. The linearity of the absorbance-concentration curve was verified at $0-300 \mu \mathrm{g} / \mathrm{ml}\left(\mathrm{R}^{2}=0.999\right)$. Results are expressed as $\mu \mathrm{g} / \mathrm{ml}$ of malvidin-3-glucoside equivalent.

Cell culture. hMSCs, frozen following the first passage in culture, were purchased from Stemcell Technologies, Inc. (cat. no. 70022; Human Bone Marrow Stromal Cells, Primary human cells, Cryo, $7.5 \times 10^{5}$ cells). Cells were obtained using Institutional Review Board (IRB)-approved consent forms and protocols (BIOMED IRB-Bone marrow collection for therapeutic or non-therapeutic use-Protocol number 701-01). On receipt, they were cultured at standard conditions of $37^{\circ} \mathrm{C}$ and $5 \% \mathrm{CO}_{2}$, and maintained in MesenCult ${ }^{\mathrm{TM}}$ Proliferation kit (Human; cat. no. 05411), supplemented with L-Glutamine (200 mM; cat. no. 07100), both from Stemcell Technologies, Inc. Experiments were performed with hMSCs at passage 2 or 3 following receipt.

On day 0 of the preliminary experiments, cells were seeded in 2 different 12 well-plates (Sarstedt AG \& Co. KG) at a density of $\sim 5 \times 10^{4}$ cells $/ \mathrm{ml}$, placing $2 \mathrm{ml}$ into each well. After $24 \mathrm{~h}$, the medium was changed and replaced with new medium. In each plate, the first column ( 3 wells) of the plate was used as the control and did not receive any further supplement. Columns 2 and 3 received $10 \mu \mathrm{g} / \mathrm{ml}$ Arneis and Croatina PRPEs, respectively. A further control was obtained by culturing hMSC in osteogenic growth medium (cat. no. 05465, MesenCult ${ }^{\mathrm{TM}}$ Osteogenic Diff kit; Human; Stemcell Technologies, Inc.) in the fourth column of the plate.

At the first experimental time point (5 days), one plate was used for RT-qPCR analysis, as described in the next paragraph. The second plate received $0.5 \mathrm{ml}$ fresh medium and relevant analysis was performed on day 12 . 
Based on the obtained results, as described in the relevant section, a further experiment was planned, using the same general approach but working at two different PRPE concentrations (10 and $20 \mu \mathrm{g} / \mathrm{ml})$. A dedicated 12-well plate for each concentration and each experimental time point (total 4 12-well plates) was prepared according to the experimental scheme described for the preliminary experiment. Measurements were performed after $48 \mathrm{~h}$ and 7 days.

$R T-q P C R$ analysis. Total RNA was isolated from hMSCs using the Maxwell ${ }^{\circledR}$ RSC simply RNA Cells kit (Promega Corporation) in the Maxwell ${ }^{\circledR}$ RSC instrument (Promega Corporation), following the manufacturer's protocol. RNA quantification was performed using the Quantifluor system kit in the Quantus Fluorometer (both from Promega Corporation) and the obtained total RNA was reverse-transcribed using a High-Capacity cDNA Reverse Transcription kit in the Thermal Cycler 2720 (both from Thermo Fisher Scientific, Inc.) at the following conditions: $10 \mathrm{~min}$ at $25^{\circ} \mathrm{C}, 120 \mathrm{~min}$ at $37^{\circ} \mathrm{C}, 5 \mathrm{~min}$ at $85^{\circ} \mathrm{C}$ and were maintined at $4^{\circ} \mathrm{C}$ until further experimentation. RT-qPCR was performed, following the Fast running protocol of the TaqMan ${ }^{\circledR}$ FastAdvanced Master Mix (Thermo Fisher Scientific, Inc.), in the QuantStudio 5 Real Time PCR System (Thermo Fisher Scientific, Inc.) using designed TaqMan ${ }^{\circledR}$ assays (Thermo Fisher Scientific, Inc.) to quantify gene expression of human tyrosine 3-monooxygenase/tryptophan 5-monooxygenase activation protein $\zeta$ (YWHAZ; Hs03044281_g1), a 1 type 1 collagen (Colla1; Hs00164004_m1), alkaline phosphatase (ALPL; Hs01029144_m1), osteocalcin (OCN; Hs00609452_g1), osteonectin (SPARC; Hs00234160_m1), metalloproteinase (MMP)1 (Hs00899658_m1), tissue inhibitor of metalloproteinase (TIMP)1 (Hs01092512_g1), Runx2 (Hs01047976_m1), BMP2 (Hs00154192_m1), integrin-binding sialoprotein (IBSP) (Hs00173720_m1), receptor activator of nuclear factor к-B ligand (RANKL; Hs00243519_m1) and osteoprotegerin (OPG; Hs00900358_m1), and all transcripts were normalized to YWHAZ. Data have been normalized using the comparative threshold cycle ${ }^{\Delta \Delta \mathrm{Cq})}$ method (54).

Statistical analysis. Experimental data were analyzed using PAST version 3.18 (55) and results are presented as the mean \pm standard error of the mean from 3 independent experiments ( 3 wells for each set of data). Statistical differences between groups were analysed using two-way ANOVA, followed by Tukey's post-hoc test. $\mathrm{P}<0.05$ was considered to indicate a statistically significant difference.

\section{Results}

Grape pomace extract characterization. Prior to the in vitro study, a prerequisite was the identification and quantification of the polyphenolic pattern by different techniques. Two different types of grape pomace were used as a source of polyphenols: Arneis and Croatina. Analysis of phenolic content showed an initial amount of $3.6 \mathrm{mg} / \mathrm{ml}$ of GAE for Croatina PRPE and $5.5 \mathrm{mg} / \mathrm{ml}$ of GAE for Arneis PRPE. The detection of a higher GAE value in white grape pomace is likely the outcome of the mentioned different technique of white vs. red wine-making. Starting from that value, the two extracts were diluted with water to reach the same amount of phenolic content, equal to $1 \mathrm{mg} / \mathrm{ml} \mathrm{GAE}$ and then HPLC-DAD analysis and related antioxidant power were performed.

The analysis of the UV-Vis spectra of the peaks found in the chromatograms allowed the classification of the separated peaks (Figs. S1 and S2) in different classes: Phenolic acid and flavonoids, which exhibit an absorbance maximum of 277-280 nm, hydroxycinnamic acid of 313-330 nm with sometimes a shoulder of $290 \mathrm{~nm}$, flavonols of $350-385 \mathrm{~nm}$ and anthocyanidines, which show an absorbance maximum of 280-320 nm with specific absorbance at $525 \mathrm{~nm}$ (56).

The different composition of PRPEs $(1 \mathrm{mg} / \mathrm{ml}$ of GAE) is well represented in Figs. 1 and 2, which contain the chromatograms of the two extracts, obtained through HPLC-DAD.

The baseline drift is one of the issues of the HPLC analysis and, aiming at reducing it, the use of a gradient characterized by the same solvent used both at the beginning and at the end of the analysis and that has a low absorbance cut-off is recommended $(57,58)$.

In order to reduce the baseline drift, in the present analysis acetonitrile was used as solvent, which has a low cut-off wavelength and is different from the absorbance wavelength of the compound (>280 $\mathrm{nm}$ ). This resulted in a very low baseline drift at the wavelength of $280 \mathrm{~nm}$ (Figs. 1 and 2). The chromatograms corresponding to the Croatina extract (Fig. 2) at the wavelengths of $320,355,370$ and $520 \mathrm{~nm}$ seem to have a more evident baseline drift corresponding to the Arneis extract (Fig. 1) but this is due to the y axis scale (intensity) which is smaller and, as a consequence, amplified.

The chromatograms corresponding to the 2 grape PRPEs showed a particular and distinctive phenolic profile, with a good separation that created the fingerprint of the extracted residual phenolics. Using different standard solutions, it was possible to identify and quantify the specific polyphenols for each extract: Quercetin, rutin, GA, caffeic acid, p-coumaric acid and malvidin-3-glucoside (Table II).

The obtained results showed a significant difference in the amount of phenolic acid: The amount of GA was $9.42 \mu \mathrm{g} / \mathrm{ml}$ for Croatina and $2.83 \mu \mathrm{g} / \mathrm{ml}$ for Arneis. The amount of the quercetin flavonol was similar in the 2 extracts, whereas that of rutin, a flavonoid glycoside, was significantly increased in the Arneis PRPE, as compared to Croatina PRPE (18.07 and $0.19 \mu \mathrm{g} / \mathrm{ml}$, respectively).

Both extracts contained a similar amount of caffeic and coumaric acid (see Table II). Croatina PRPE is mainly composed of anthocyanidines. As seen in Table II, the amount of malvidin-3-glucoside found in the chromatogram of Croatina PRPE is $37.2 \mu \mathrm{g} / \mathrm{ml}$, as compared with the $0 \mu \mathrm{g} / \mathrm{ml}$ of Arneis PRPE.

The total amount of anthocyanins was further determined using the Ribéreau-Gayon and Stonestreet methods (53), which exploit the bleaching potential of sodium bisulphite, which reveals that $446.7 \mu \mathrm{g} / \mathrm{ml}$ of anthocyanins are present in Croatina PRPE, whereas $\sim 3.7 \mu \mathrm{g} / \mathrm{ml}$ of anthocyanins are present in Arneis PRPE (Table III).

The free radical scavenging capacity of both extracts has also been evaluated by DPPH assay, which is considered a valid, accurate, easy and economic method to evaluate the radical scavenging activity of antioxidants, since the radical 

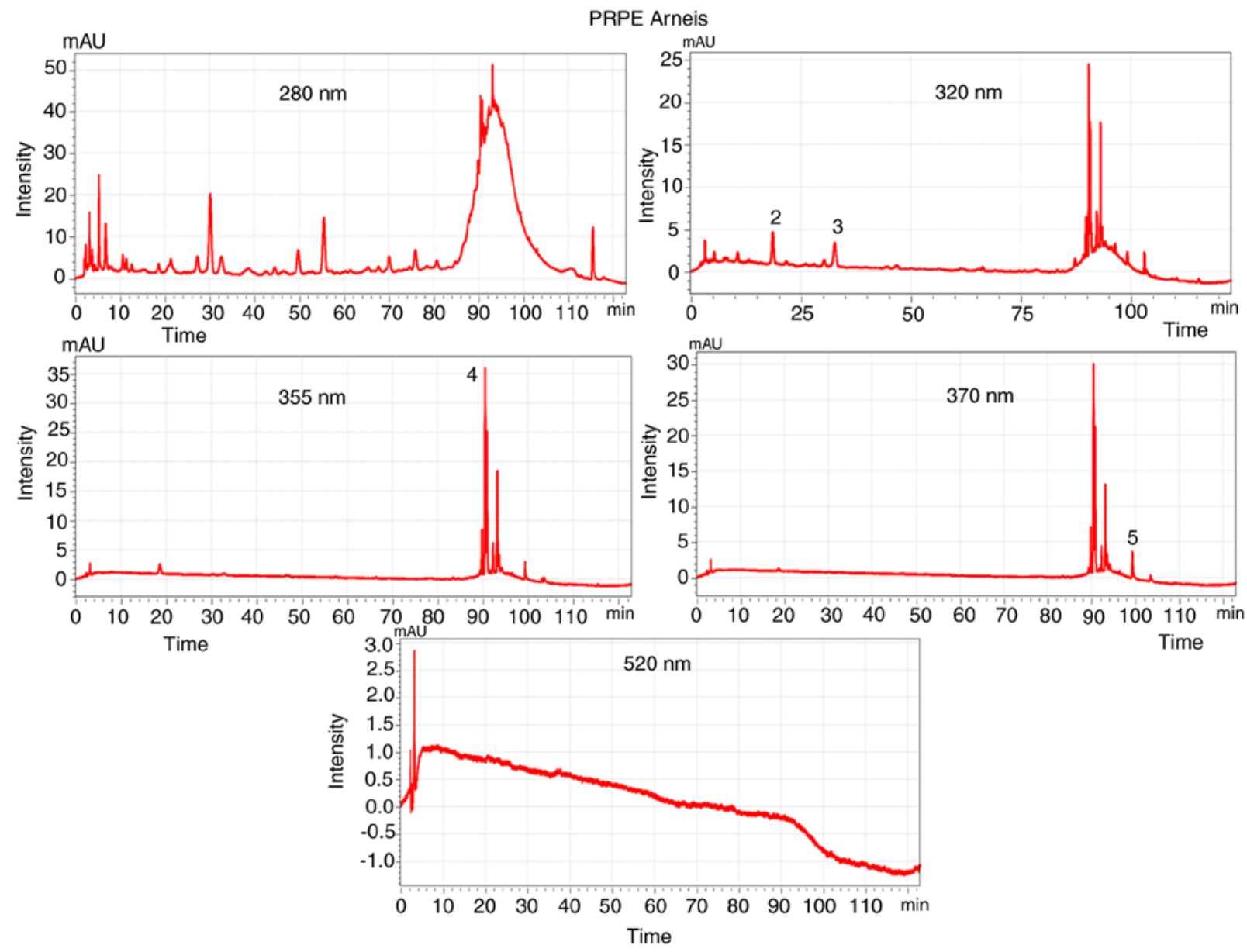

Figure 1. High-performance liquid chromatography analysis of PRPEs from Arneis at $1 \mathrm{mg} / \mathrm{ml}$ of gallic acid equivalents. Chromatograms of PRPEs of Arneis at $280 \mathrm{~nm}$. PRPEs, polyphenol-rich pomace extracts.

compound is stable and needs not to be generated. The antioxidant power for both PRPEs at $1 \mathrm{mg} / \mathrm{ml}$ of GAE was analyzed. Results reported in Table IV showed that PRPEs with the same phenolic content can reduce radicals with a different efficacy. In particular, Arneis PRPE reduces radicals by $41.8 \%$, whereas Croatina PRPE reduced by $18.5 \%$, suggesting that, with the same polyphenolic content $(1 \mathrm{mg} / \mathrm{ml})$, the molecules contained in pomace from Arneis exert a higher antioxidant power, as compared with pomace from Croatina.

Gene expression analysis by $R T-q P C R$. The qPCR experiment was set up following a series of preliminary screening tests, in order to determine the best concentrations of polyphenols extracts at different time points in terms of cell viability and biological activity (data not shown). In particular, for the evaluation of cell viability depending on PRPEs concentrations and time, the MTT assay was used, followed by RT-qPCR to evaluate gene expression analysis as a response of cells to the not cytotoxic concentrations of PRPEs.

The expression of genes associated with hMSC differentiation into osteoblasts was examined by RT-qPCR, however the absence of experiments investigating both the molecular mechanisms involved in the observed polyphenols actions and the protein levels is a limitation of the present study. The first experiment, at two different time points (5 and 12 days), was carried out with a low concentration ( $\mathrm{LC}=10 \mu \mathrm{g} / \mathrm{ml}$ ) of extracts, as compared with a control containing hMSCs incubated in basal growth medium for 5 days. An osteogenic treatment on hMSCs, grown in osteogenic growth medium (OGM), was also administered to further investigate the differentiation potential of the two grape PRPEs. Incubation of hMSCs with both low-concentration (LC) PRPEs resulted in an increase of the expression levels of genes involved in the induction of osteogenic differentiation, such as BMP2 and Runx 2 at both time points, as compared with negative control and osteogenic cells (Fig. 3).

Specifically, BMP2 gene expression in hMSCs treated with LC Arneis PRPE, increased by 1.7 at 5 days and 2.4-fold at 12 days (not significant), whereas the Runx 2 expression increased by 2.7 -fold $(\mathrm{P}<0.001)$ at 5 days and 3.9 -fold $(\mathrm{P}<0.0001)$ at 12 days, as compared with hMSCs at 5 days. Furthermore, the expression value of cells with LC Arneis PRPE at 12 days, is also greater than that of osteogenic cells at 12 days $(\mathrm{P}<0.0001)$.

Unexpectedly, for cells incubated with LC Croatina PRPE, analysis of IBSP showed a significantly increased gene expression (1.6-fold) at 5 days, as compared with the control $(\mathrm{P}<0.05)$ and osteogenic cells $(\mathrm{P}<0.0001)$ at 5 days, and to osteogenic cells at 12 days $(\mathrm{P}<0.0001)$. Furthermore, LC Arneis PRPE significantly induced IBSP expression at both time points, as compared with osteogenic cells $(\mathrm{P}<0.05$, at 5 days and $\mathrm{P}<0.0001$ at 12 days; Fig. 3). 


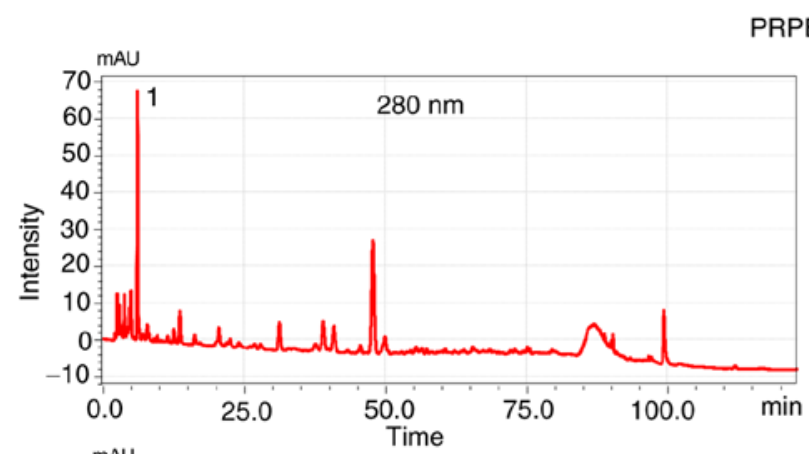

RPE Croatina
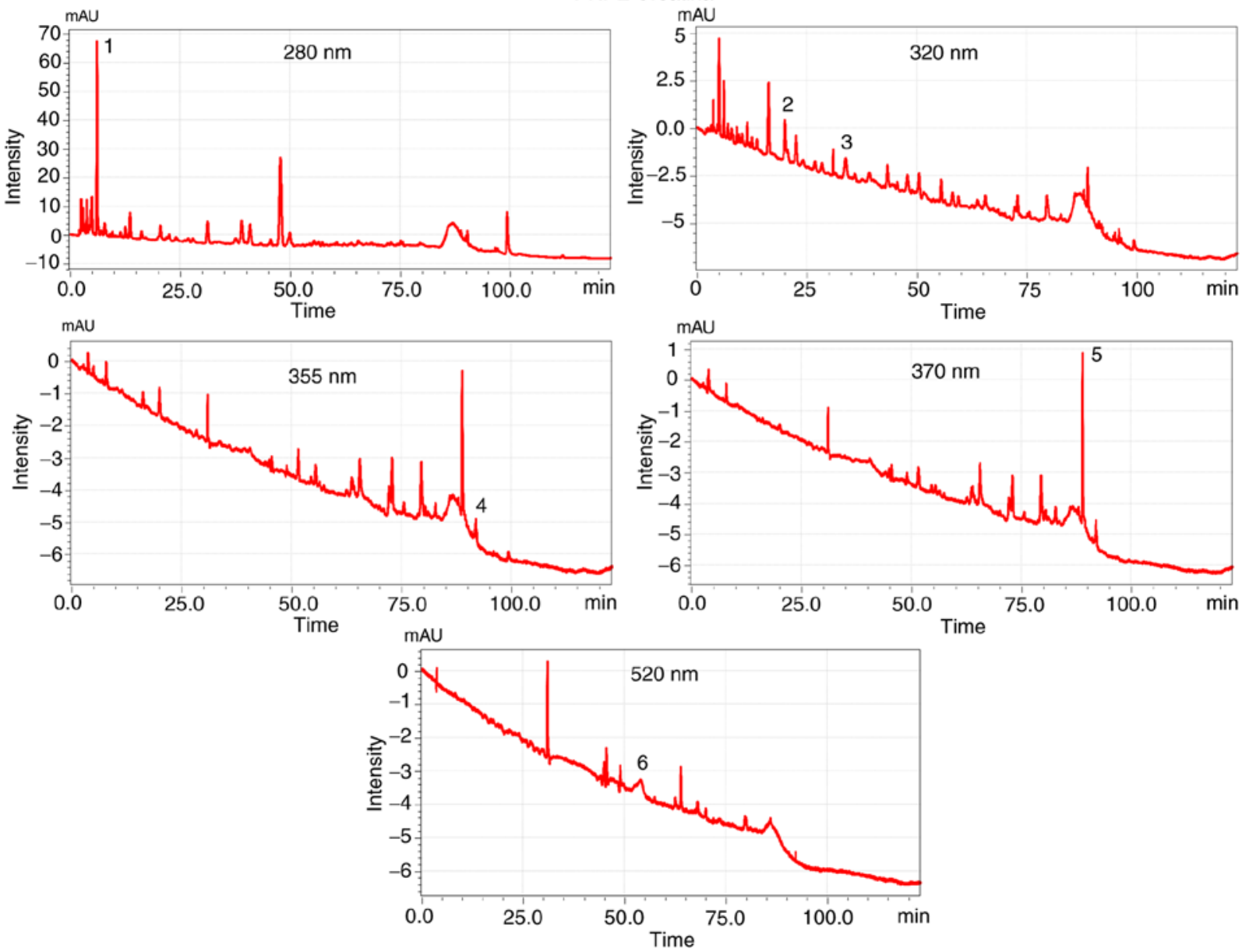

Figure 2. High-performance liquid chromatography analysis of PRPEs from Croatina at $1 \mathrm{mg} / \mathrm{ml}$ of gallic acid equivalents. Chromatograms of PRPEs of Croatina at $280 \mathrm{~nm}$. PRPEs, polyphenol-rich pomace extracts.

These promising results led the current study to further investigate additional genes and evaluate whether the effects seen on hMSCs, following incubation for $48 \mathrm{~h}$ and 7 days with the two tested PRPEs, were dose-dependent; two concentrations, namely $\mathrm{LC}$ and high concentration $(\mathrm{HC}=20 \mu \mathrm{g} / \mathrm{ml})$, were therefore used.

Enhancement of bone matrix protein expression of genes such as Colla1 and SPARC can be observed in cells incubated with LC Arneis PRPE (Colla1, 1.9-fold at $48 \mathrm{~h}, \mathrm{P}<0.001$; 4.7-fold at 7 days, $\mathrm{P}<0.0001$; SPARC, 1.7 -fold at $48 \mathrm{~h}, \mathrm{P}<0.001$; 4.7-fold at 7 days, $\mathrm{P}<0.0001$ ) and in HC Arneis PRPE (Col1a1, 2.1-fold at $48 \mathrm{~h}, \mathrm{P}<0.0001$; SPARC, 2.1-fold at $48 \mathrm{~h}, \mathrm{P}<0.0001$ ), as compared with the control (Fig. 4).

Of note, as compared with osteogenic cells, those incubated with Arneis PRPE had a significantly increased Colla1 expression (LC at 7 days, $\mathrm{P}<0.0001$ ) and SPARC levels ( $\mathrm{LC}$ at $48 \mathrm{~h} \mathrm{P}<0.05$, at 7 days $\mathrm{P}<0.0001 ; \mathrm{HC}$ at $48 \mathrm{~h} \mathrm{P}<0.001$, at 7 days, $\mathrm{P}<0.0001)$, whereas cells with Croatina PRPE only showed a significant increase of SPARC (LC and $\mathrm{HC}$ at $48 \mathrm{~h}$ and 7 days, $\mathrm{P}<0.0001$; Fig. 4). Analysis of mineralization-related genes such as ALPL and OCN showed a significant increase of OCN expression in cells incubated with Arneis PRPE (HC at $48 \mathrm{~h}$; $\mathrm{P}<0.001$ ), as compared with the control (Fig. 5), whereas no differences were found for ALPL expression (Fig. S3).

Given that the osteogenic differentiation process is also influenced by the perturbation of subtle equilibria, the opposite actions of MMPs and tissue inhibitor of metalloproteinases (TIMPs) have been investigated. In particular, as compared with the control, only LC Arneis PRPE at 48 h showed a reduced MMP1 expression (0.1-fold; $\mathrm{P}<0.01$ ), whereas the TIMP1 expression was significantly increased in all PRPEs at 7 days, as compared with cells grown in OGM (LC Arneis, $\mathrm{P}<0.0001$; LC Croatina, $\mathrm{P}<0.0001$; HC Arneis, $\mathrm{P}<0.001$; HC Croatina, $\mathrm{P}<0.0001$; Fig. 4). Particularly interesting was the analysis of the MMP1/TIMP1 ratio, which the 2 PRPEs decreased at $48 \mathrm{~h}$ (Arneis LC, $\mathrm{P}<0.0001$ and $\mathrm{HC}, \mathrm{P}<0.01$; Croatina LC, $\mathrm{P}<0.05$ and HC, $\mathrm{P}<0.01$; Table $\mathrm{V}$ and Fig. 6).

Furthermore, Runx2 analysis showed increased transcript levels in cells incubated with HC Arneis PRPE (9.5-fold; $\mathrm{P}<0.0001)$ and HC Croatina PRPE (5.7-fold; $\mathrm{P}<0.0001)$ at 7 days, as compared with control and osteogenic cells $(\mathrm{P}<0.0001$; Fig. 5). Another analyzed gene was BMP2. Only Arneis PRPE induced an increase in the BMP2 expression at $\mathrm{LC}$ at 7 days (1.7-fold; $\mathrm{P}<0.001)$ and at $\mathrm{HC}$ at both time points (48 h, 2.3-fold; 7 days, 2.7-fold; $\mathrm{P}<0.0001$ ), as compared with the control, with a significant difference also when compared with osteogenic cells, at both time points ( $48 \mathrm{~h}, \mathrm{P}<0.01 ; 7$ days, $\mathrm{P}<0.0001$; Fig. 5).

IBSP expression analysis highlighted a tendency of cells incubated in LC PRPE Arneis and Croatina and in HC PRPE Croatina (both at 48 h) to maintain a high IBSP expression 
Table II. Quantification of different polyphenol molecules through high pressure liquid chromatography-diode array detector analysis.

\begin{tabular}{lcccccc}
\hline PRPE & $\begin{array}{c}\text { Gallic } \\
\text { acid }(\mu \mathrm{g} / \mathrm{ml})\end{array}$ & $\begin{array}{c}\text { Caffeic } \\
\text { acid }(\mu \mathrm{g} / \mathrm{ml})\end{array}$ & $\begin{array}{c}\text { Cumaric } \\
\text { acid }(\mu \mathrm{g} / \mathrm{ml})\end{array}$ & $\begin{array}{c}\text { Quercetin } \\
(\mu \mathrm{g} / \mathrm{ml})\end{array}$ & $\begin{array}{c}\text { Rutin } \\
(\mu \mathrm{g} / \mathrm{ml})\end{array}$ & $\begin{array}{c}\text { Malvidin-3-glucoside } \\
(\mu \mathrm{g} / \mathrm{ml})\end{array}$ \\
\hline Croatina & 9.42 & 1.59 & 0.21 & 2.06 & 0.19 & 37.2 \\
Arneis & 2.83 & 1.41 & 0.61 & 1.84 & 18.07 & 0 \\
\hline
\end{tabular}

PRPEs, polyphenol-rich pomace extracts.

Table III. Anthocyanins content in PRPEs.

\begin{tabular}{lc}
\hline PRPE & Anthocyanins $(\mu \mathrm{g} / \mathrm{ml})$ \\
\hline Croatina & 446.7 \\
Arneis & 3.7 \\
\hline
\end{tabular}

PRPEs, polyphenol-rich pomace extracts.

Table IV. Reduction (\%) of 2,2-diphenyl-1-picrylhydrazyl radical by PRPEs from Arneis and Croatina.

\begin{tabular}{lc}
\hline PRPE & Reduction \% \\
\hline Croatina & 18.5 \\
Arneis & 41.8 \\
\hline
\end{tabular}

PRPEs, polyphenol-rich pomace extracts.

$(\mathrm{P}<0.05$ and $\mathrm{P}<0.01$, respectively; Fig. 5), as compared with osteogenic cells.

Finally, the gene expression of RANKL and its decoy receptor OPG was evaluated (Fig. 6). In particular, for RANKL levels, only LC Arneis, at $48 \mathrm{~h}$, induced a statistically significant decrease, as compared with the control (0.3-fold; $\mathrm{P}<0.01)$, whereas all PRPEs, at 7 days and at both concentrations, reduced RANKL levels, as compared with OGM cells (LC Arneis, $\mathrm{P}<0.0001$; LC Croatina, $\mathrm{P}<0.001$; HC Arneis, $\mathrm{P}<0.0001$; HC Croatina, $\mathrm{P}<0.001)$. With regard to the OPG expression, LC Arneis and Croatina at both concentrations at $48 \mathrm{~h}$, showed increased expression levels (LC Arneis, 2.5-fold; LC Croatina, 1.9-fold; HC Croatina, 1.9-fold), as compared with the control $(\mathrm{P}<0.001$ for all), whereas at 7 days, this enhancing effect was observed only in cells incubated with Croatina at both concentrations ( $\mathrm{LC}, \mathrm{P}<0.01$ and $\mathrm{HC}$, $\mathrm{P}<0.0001$; Fig. 6). Of note, as compared with OGM cells at both time points, these results are of particular significance ( $\mathrm{P}<0.0001$ for all, at both time points) and, by taking a look at the RANKL/OPG ratio, both concentrations of the 2 PRPEs significantly reduced the RANKL/OPG ratio, as compared with the control at $48 \mathrm{~h}$ (LC Arneis, $\mathrm{P}<0.0001$; LC Croatina, $\mathrm{P}<0.001$; HC Arneis, $\mathrm{P}<0.0011$ HC Croatina, $\mathrm{P}<0.01 ; 7$ days, all PRPEs concentrations, $\mathrm{P}<0.0001)$ and osteogenic cells at both time points $(\mathrm{P}<0.0001$; Table VI and Fig. 6).

\section{Discussion}

Polyphenols have always been recognized as compounds with health benefits; their well-known anti-oxidant and anti-inflammatory properties make them attractive therapeutic agents for different inflammatory conditions (1). Several studies have investigated their ability to improve and maintain bone health, with different results showing clear positive effects on osteoblast differentiation, bone mass regeneration through the enhancement of osteoblastogenesis and inhibition of osteoclastogenesis and mitigation of bone loss $(59,60)$.

Direct osteoinductive effects of polyphenols on osteoblast differentiation, proliferation and protection have been well documented $(21,22)$ and, as such, several bioactive polyphenols-coated biomaterials have been engineered (30-38), in order to improve osteogenesis and bone mineralization. Despite the different content of phenolic classes in the tested PRPEs, a common trend of hMSC stimulation has been observed, suggesting that widely available, easy-to-obtain PRPEs can play a role in the biochemical modification of dental materials and devices. The PRPEs used in the present study had different chromatograms, suggesting different molecular compositions. In particular, extracts from red grape pomace Croatina are characterized by proanthocyanidins, flavonoids (flavonols and flavones) and hydroxycinnamic acids. By contrast, extracts from white grape pomace Arneis are mostly composed by phenolic and hydroxycinnamic acids and contain a lower number of anthocyanins, as compared with Croatina PRPE. Proanthocyanidins were investigated in vivo by Kojima et al (61) and exhibited an increase of total and cortical bone mass in rat mandibular condyles, in which bone fragility had been induced.

The importance of polyphenols as bioactive molecules is represented by their ability to trigger different cell responses through the activation of diverse biological pathways that ultimately lead to the modulation of inflammation, oxidative stress and cell differentiation; thus their application in dental and oral health could contribute to preventing or treating chronic pathological conditions, such as periodontal disease. In particular, polyphenols could enhance periodontal MSC regeneration properties through both the modulation of the inflammatory periodontal environment and the stimulation of osteogenic genes.

In the present study, PRPE actions on hMSCs were investigated by RT-qPCR, in order to understand the effect of different groups of polyphenols on osteogenic differentiation; in fact, in the periodontium, MSCs reside in the periodontal ligament and alveolar bone and differentiate into bone-forming cells. 


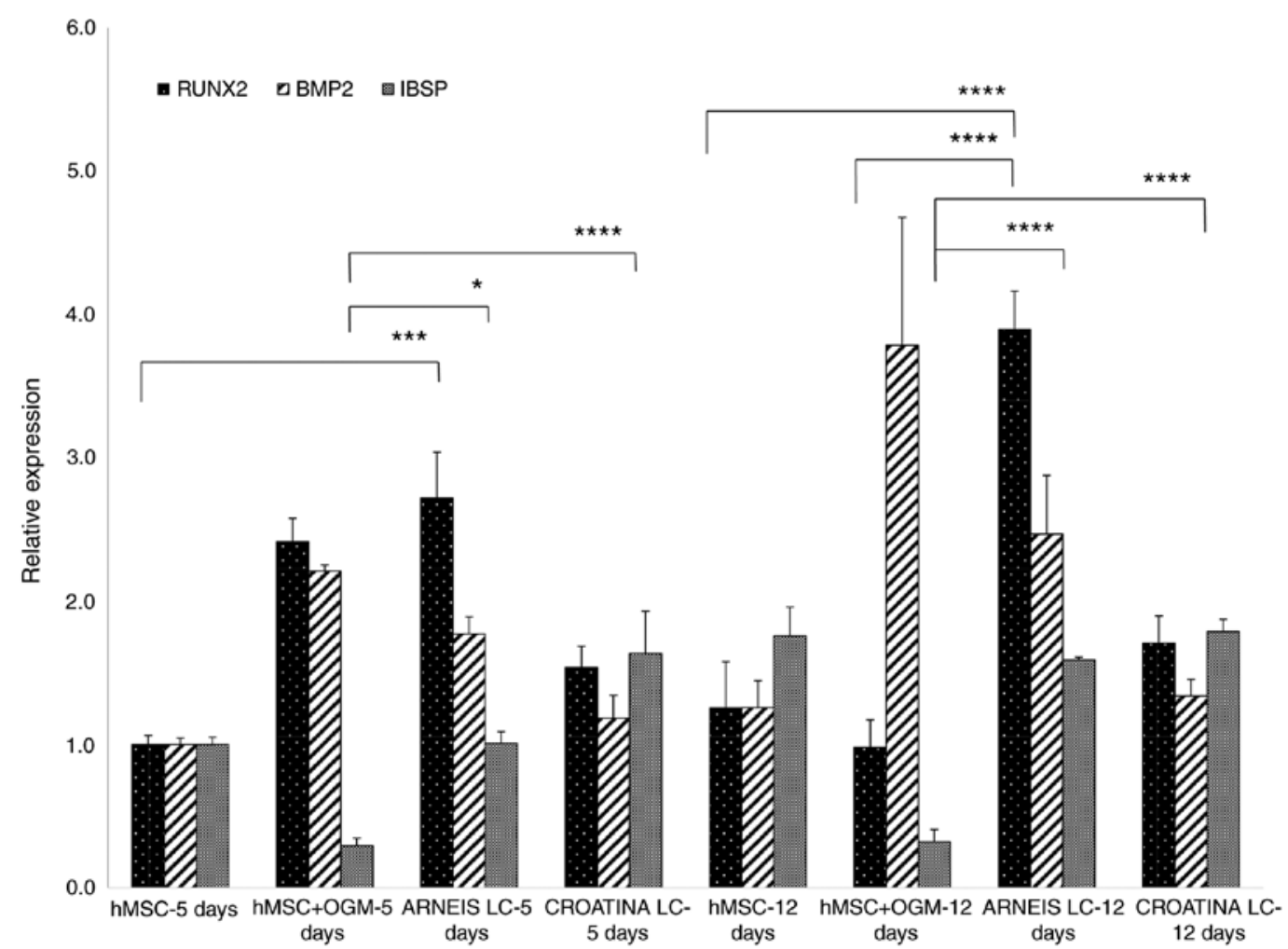

Figure 3. Preliminary reverse transcription-quantitative PCR experiment. Gene expression analysis of hMSCs incubated with OGM or LC Arneis and Croatina PRPEs, at 5 and 12 days. Values are expressed as relative expression, compared with the control group. Data are presented as the mean \pm standard error of the mean. ${ }^{*} \mathrm{P} \leq 0.05,{ }^{* * *} \mathrm{P} \leq 0.001$ and ${ }^{* * * *} \mathrm{P} \leq 0.0001$. hMSCs, human mesenchymal cells; OGM, osteogenic growth medium; LC, low concentration; PRPEs, polyphenol-rich pomace extracts; iBSP, integrin-binding sialoprotein; BMP2, bone morphogenetic protein 2; Runx2, runt-related transcription factor 2.

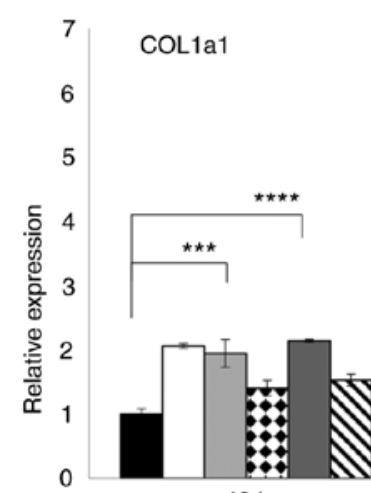

$48 \mathrm{~h}$

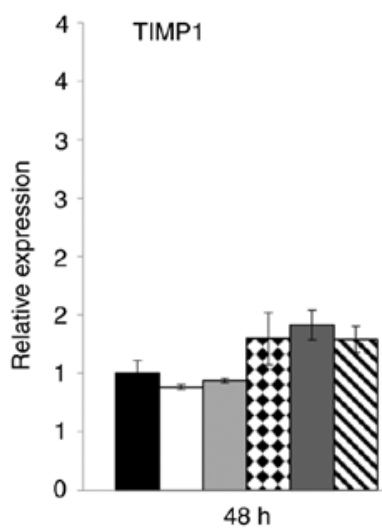

$48 \mathrm{~h}$

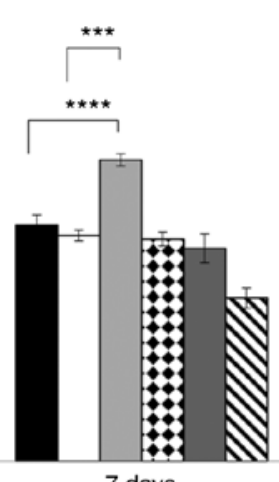

7 days

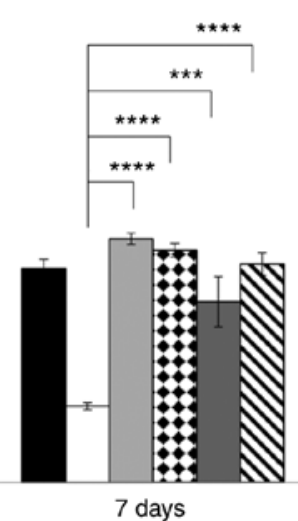

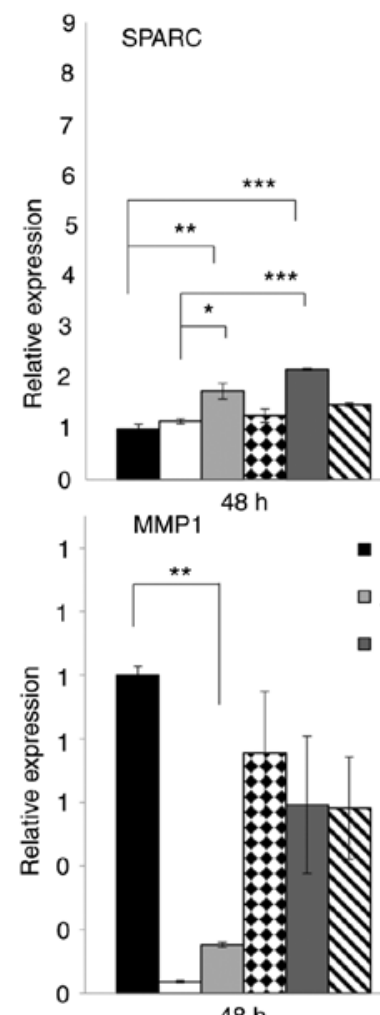

$48 \mathrm{~h}$
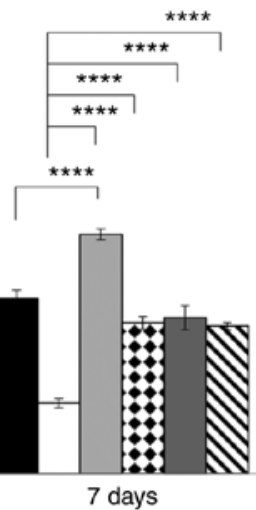

hMSCs

口 hMSCs+OGM

$\square$ Arneis LC

a Croatina LC

Arneis $\mathrm{HC} \otimes$ Croatina $\mathrm{HC}$

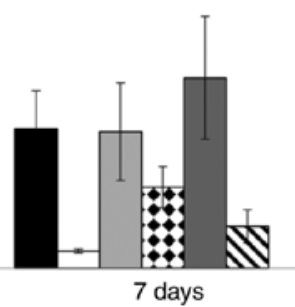

Figure 4. Gene expression analysis of Col1a1, SPARC, TIMP1 and MMP1 at the mRNA level. Reverse transcription-quantitative PCR data for Colla1, SPARC, TIMP1 and MMP1 genes obtained after $48 \mathrm{~h}$ and 7 days for untreated and treated groups cultured in OGM or Arneis and Croatina PRPEs. Values are expressed as relative expression, compared with the control group. Data are presented as the mean \pm standard error of the mean. ${ }^{*} \mathrm{P} \leq 0.05,{ }^{* * *} \mathrm{P} \leq 0.01,{ }^{* * * *} \mathrm{P} \leq 0.001$ and ${ }^{* * * * *} \mathrm{P} \leq 0.0001$. Colla1, $\alpha 1$ type 1 collagen; SPARC, secreted protein acidic and cysteine rich; TIMP1, tissue inhibitor of metalloproteinase 1; MMP1, metalloproteinase 1; OGM, osteogenic growth medium; PRPEs, polyphenol-rich pomace extracts; LC, low concentration; HC, high concentration. 

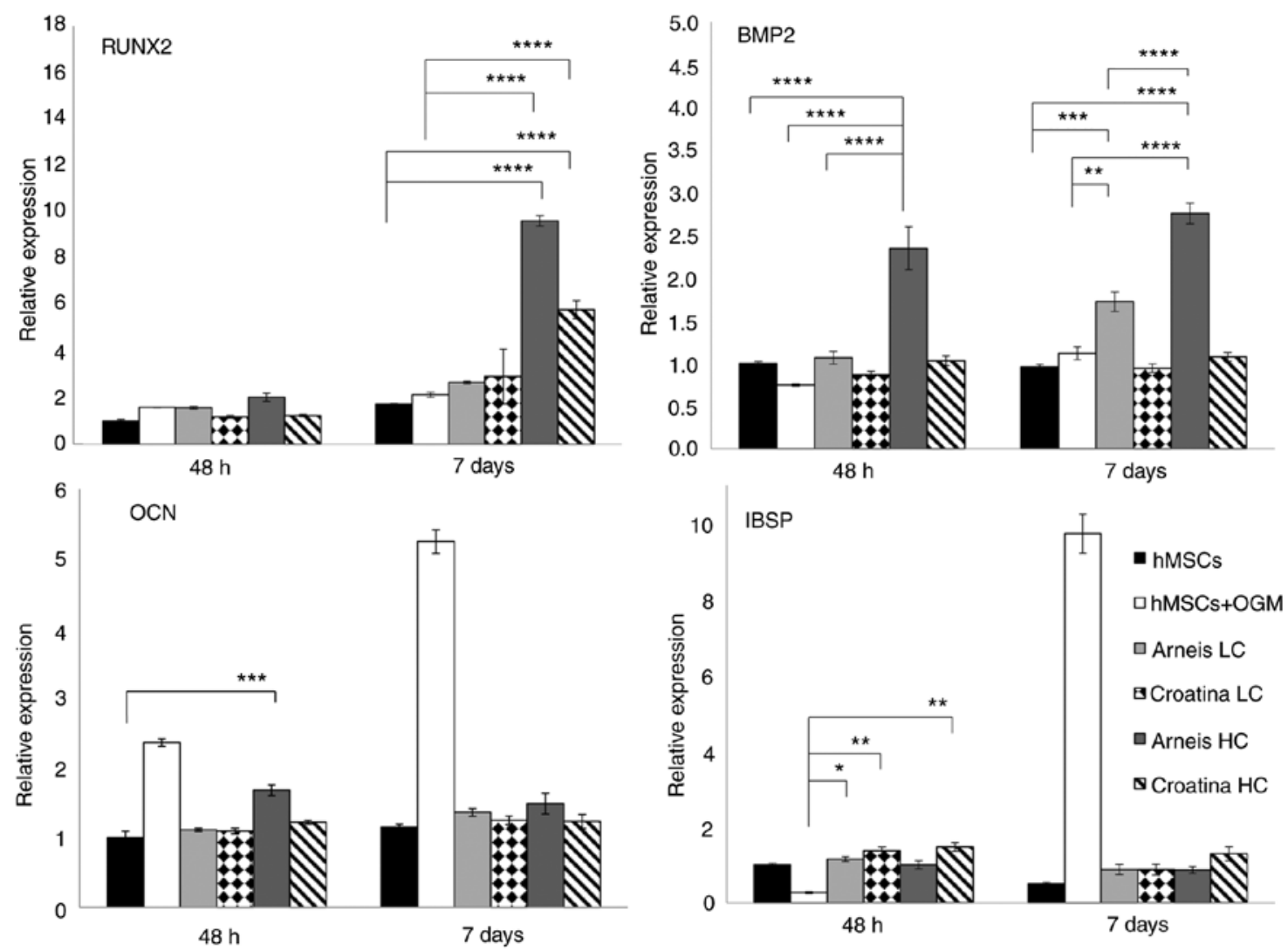

Figure 5. Gene expression analysis of Runx2, BMP2, OCN and IBSP at the mRNA level. Reverse transcription-quantitative PCR data for Runx2, BMP2, OCN and IBSP genes obtained after $48 \mathrm{~h}$ and 7 days for untreated and treated groups cultured in osteogenic differentiation media or Arneis and Croatina PRPEs. Values are expressed as relative expression, compared with the control group. Data are presented as the mean \pm standard error of the mean. ${ }^{*} \mathrm{P} \leq 0.05,{ }^{* *} \mathrm{P} \leq 0.01$, ${ }^{* * *} \mathrm{P} \leq 0.001$ and ${ }^{* * * * *} \mathrm{P} \leq 0.0001$. Runx2, runt-related transcription factor 2; BMP2, bone morphogenetic protein 2; OCN, osteocalcin; IBSP, integrin-binding sialoprotein; PRPEs, polyphenol-rich pomace extracts; LC, low concentration; HC, high concentration.

Gene expression analysis of hMSCs provided insight into the effects exerted by PRPEs on the osteogenic differentiation in hMSCs, with promising results that however need to be further explored from a mechanistic point of view.

The present results clearly indicated that polyphenols from Arneis and Croatina extracts display interesting osteoinductive properties that result in the activation of BMP2 and Runx2 gene expression, in addition to the stimulation of hMSCs towards an early osteoblast differentiation stage, as shown by an increase in the expression of the Collal and SPARC genes [which are involved in the deposition of extracellular matrix (ECM) that occurs at the first stages of bone formation] and by the low transcript levels of the mineralization-related genes alkaline phosphatase and osteocalcin (OCN; which are expressed at more mature stages of osteoblast differentiation).

In particular, the BMP2 and Runx2 increase was shown to be induced by Arneis PRPE, which is particularly rich in the flavonoid glycoside rutin. Flavonoid glycosides have been shown to possess a high osteogenic potential related to the stimulation of BMP2 and Runx2 expression (62-67). More generally, polyphenols are able to enhance osteoblast activity and differentiation, by targeting Runx 2 through different signaling pathways $(16,50,68-70)$ and by inducing the expression of bone-matrix related genes (71-74). The different extent of BMP2 expression induced by the 2 PRPEs suggested that their different phenolic composition might determine the activation of diverse signaling pathways implicated in the regulation of
Runx2 expression. In particular, the higher BMP2 and Runx2 expression in Arneis PRPE, as compared with Croatina PRPE, could be ascribed to the higher rutin content in Arneis PRPE, through a possible mechanism involving the modulation of the ER pathway (75). Indeed, rutin has been shown to downregulate the RUNX suppressor genes (76) and exert its osteogenic effect through an ER-mediated mechanism (77), thus providing the basis for hypothesizing that the increased BMP2 expression is induced by Arneis PRPE through the activation of the ER (78). Another factor to consider is the different antioxidant power exhibited by the two extracts. In fact, given the tendency of flavonoids to interact with each other when present in a mixture, the global antioxidant power is the result of synergistic or antagonistic effects between the various possible combinations of molecules (79). In light of this, as already shown by Galanakis et al (80), the lower concentration of anthocyanidins in Arneis PRPE could account for its higher antioxidant potential, as compared with Croatina PRPE.

Thanks to their free-radical-scavenging effect, polyphenols from Arneis and, to a lesser extent, Croatina PRPEs may exert a pro-osteogenic effect by also regulating mitochondrial stress; in fact during MSC osteogenic differentiation, mitochondria require an increased oxygen consumption rate (81).

To investigate the effect of PRPEs on the inflammation-derived bone resorption, the expression of the key differentiation factor for osteoclastogenesis, RANKL, was analyzed. 
Table V. MMP1/TIMP1 ratio. MMP1 and TIMP1 RQ ratio.

\begin{tabular}{lccc}
\hline & \multicolumn{2}{c}{ RQ values } & \\
\cline { 2 - 3 } SAMPLES & MMP1 & TIMP1 & $\begin{array}{c}\text { MMP1/TIMP1 } \\
\text { RATIO }\end{array}$ \\
\hline hMSC-48 h & 1.000 & 1.000 & 1.000 \\
hMSC+OGM-48 h & 0.036 & 0.881 & 0.041 \\
ARNEIS LC-48 h & 0.152 & 0.938 & 0.162 \\
CROATINA LC-48 h & 0.755 & 1.298 & 0.582 \\
ARNEIS HC-48 h & 0.593 & 1.414 & 0.419 \\
CROATINA HC-48 h & 0.582 & 1.290 & 0.451 \\
hMSC-7 days & 0.438 & 1.831 & 0.239 \\
hMSC+OGM-7 days & 0.054 & 0.650 & 0.083 \\
ARNEIS LC-7 days & 0.430 & 2.085 & 0.206 \\
CROATINA LC-7 days & 0.255 & 1.987 & 0.128 \\
ARNEIS HC-7 days & 0.599 & 1.545 & 0.388 \\
CROATINA HC-7 days & 0.131 & 1.866 & 0.070 \\
\hline
\end{tabular}

RQ, relative quantity; $\mathrm{HC}$, high concentration; $\mathrm{LC}$, low concentration; hMSCs, human mesenchymal cells; MMP1, metalloproteinase 1; TIMP1, tissue inhibitor of metalloproteinase 1 .
Table VI. RANKL/OPG ratio. RANKL and OPG RQ ratio.

\begin{tabular}{lccc}
\hline \multirow{2}{*}{ SAMPLES } & \multicolumn{2}{c}{ RQ values } & \\
\cline { 2 - 3 } & RANKL & OPG & $\begin{array}{c}\text { RANKL/OPG } \\
\text { RATIO }\end{array}$ \\
\hline hMSC-48 h & 1.000 & 1.000 & 1.000 \\
hMSC+OGM-48 h & 0.707 & 0.789 & 0.897 \\
ARNEIS LC-48 h & 0.300 & 2.533 & 0.118 \\
CROATINA LC-48 h & 0.987 & 1.954 & 0.505 \\
ARNEIS HC-48 h & 0.653 & 1.288 & 0.507 \\
CROATINA HC-48 h & 0.852 & 1.970 & 0.433 \\
hMSC-7 days & 0.389 & 2.153 & 0.181 \\
hMSC+OGM-7 days & 1.264 & 1.302 & 0.971 \\
ARNEIS LC-7 days & 0.205 & 2.430 & 0.084 \\
CROATINA LC-7 days & 0.379 & 3.033 & 0.125 \\
ARNEIS HC-7 days & 0.215 & 1.646 & 0.131 \\
CROATINA HC-7 days & 0.432 & 3.894 & 0.111 \\
\hline
\end{tabular}

RQ, relative quantity; RANKL, receptor activator of nuclear factor $\kappa$-B ligand; OPG, osteoprotegerin; HC, high concentration; LC, low concentration; hMSCs, human mesenchymal cells.
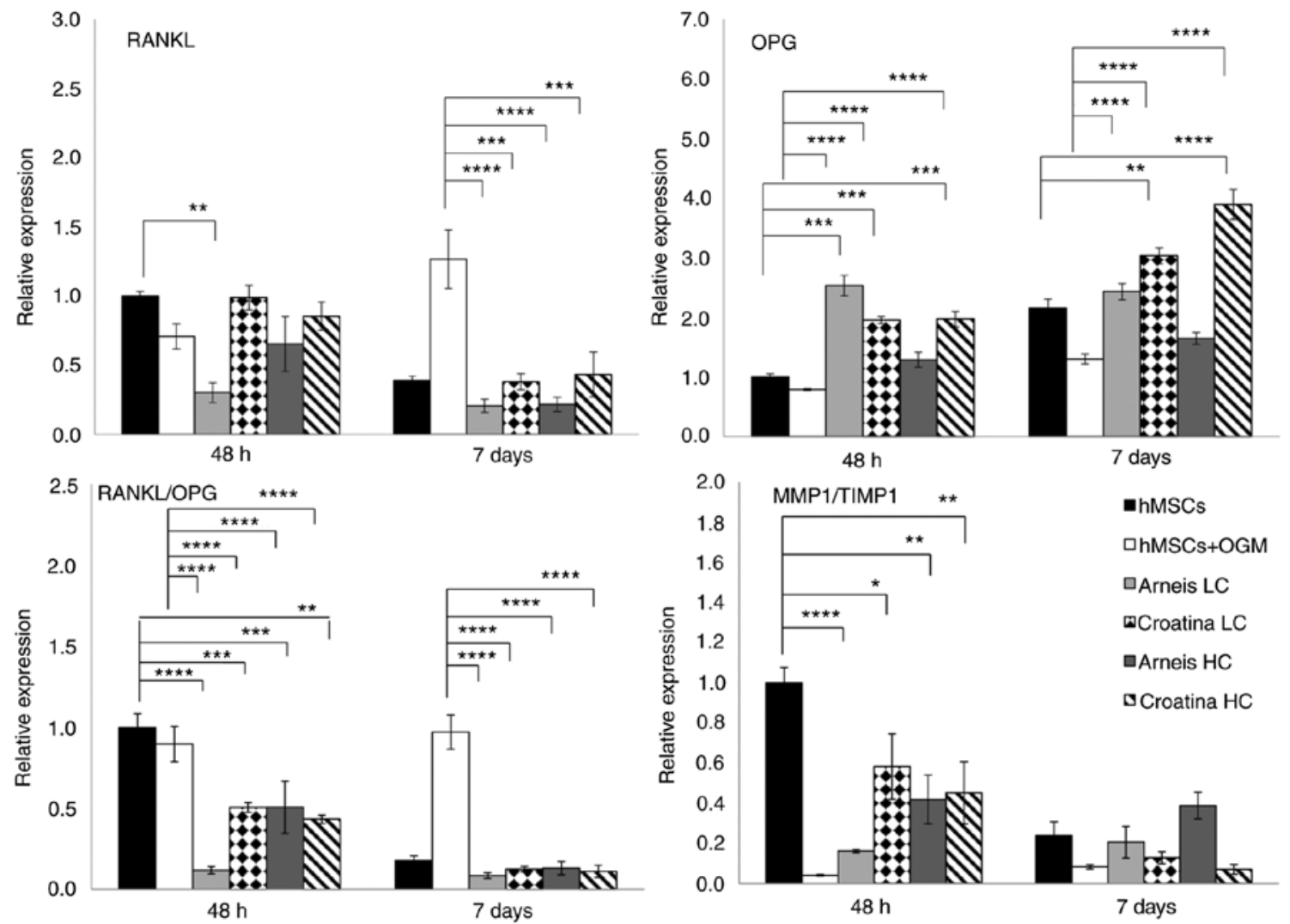

Figure 6. Gene expression analysis of RANKL, OPG, RANKL/OPG and MMP1/TIMP1 at the mRNA level. Reverse transcription-quantitative PCR data for RANKL, OPG, RANKL/OPG and MMP1/TIMP1 genes obtained after $48 \mathrm{~h}$ and 7 days for untreated and treated groups cultured in osteogenic differentiation media or Arneis and Croatina PRPEs. Values are expressed as relative expression, compared with the control group. Data are presented as the mean \pm standard error of the mean. "P $\leq 0.05,{ }^{* *} \mathrm{P} \leq 0.01,{ }^{* * *} \mathrm{P} \leq 0.001$ and ${ }^{* * * * *} \mathrm{P} \leq 0.0001$. RANKL, receptor activator of nuclear factor $\kappa-\mathrm{B}$ ligand; OPG, osteoprotegerin; MMP1, metalloproteinase 1; TIMP1, tissue inhibitor of metalloproteinase 1; PRPEs, polyphenol-rich pomace extracts.

The present results showed that RANKL is downregulated by the presence of both PRPEs, with a RANKL/OPG ratio in favor of OPG. This ratio is decreased, as compared with cells in both basal medium and OGM. The greater RANKL/OPG 
ratio observed in cells with OGM, as compared with cells incubated with PRPEs, can be explained by both a time-dependent increase of RANKL expression, induced by different cell maturation stages (82) and by the anti-inflammatory action of polyphenols (83-86), which determined the RANKL downregulation in cells treated with both PRPEs. Notwithstanding the evidence that RANKL is a member of the tumor necrosis factor family, which is not only involved in osteoclastogenesis but also in the regulation of the immune system (87), the absence of data on direct inflammation is a limitation of this study and needs to be further investigated.

This is of particular importance because osteoclastogenesis requires the signaling involving the mediator of the inflammatory response nuclear factor- $\kappa \mathrm{B}$, activated by RANKL cytokine, to occur (88).

In addition, both PRPEs exhibited a concentration-dependent effect on RANKL/OPG ratio, with a different trend suggesting the presence of multiple and competitive mechanisms, due to the specific phenolic composition. In particular, the higher antioxidant power of Arneis PRPE, due to the different flavonoid: Flavonoid interactions and the presence of rutin, which has been shown to downregulate the expression of RANKL cytokine (86), may also account for the higher RANKL downregulation, as compared with Croatina PRPE. These results are in line with those present in the literature $(89,90)$.

The investigation of MMP expression also elucidated PRPE anti-inflammatory properties; it was shown that they were involved in ECM remodeling in both normal (91-93) and pathological $(94,95)$ processes. Along with their ECM-degrading activity, which gives them a crucial role in destructive periodontal disease (96), MMPs also display multifaceted properties involved in the regulation of inflammation; in fact they have been shown to be implicated in different inflammatory disorders (97). Furthermore, as the expression of MMPs and their counteracting inhibitors, TIMPs, are differentially modulated according to MSC fate commitment (98), the evaluation of the MMP/TIMP ratio further clarified PRPE action on hMSCs differentiation.

In line with previous studies (99-101), polyphenols from both Arneis and Croatina extracts were able to decrease the MMP/TIMP ratio in the present study and, in particular, as also shown by Gòmez-Florit et al (14), the MMP1/TIMP1 ratio, and to favor hMSCs osteogenic differentiation.

It is thus not surprising that phenolic compounds display a potential for their use in the treatment of periodontitis and, more generally, for restoring and maintaining a healthy oral bone architecture. In fact, thanks to all these positive properties, polyphenols are increasingly considered for use in bone therapeutics, from applications in food and beverages, to pharmaceuticals, cosmetics and biomedical engineering.

The choice of using a mixture of phenolic compounds derived from winery wastes aims to give them new life and valorization, thanks to their content of health-promoting phytochemicals with proved bioactivity in different physiological processes (102). In particular, the grape pomace from a specific grape variety represents a valuable source of polyphenols characterized by a distinctive profile and, possibly, by a specific bioactivity.

It is clear that the different composition of PRPEs determines different cellular responses in the field of bone regeneration and specifically, in the treatment of periodontal disease, with the higher osteogenic potential of Arneis PRPE also depending on concentration. The use of PRPEs is therefore promising in the development of biomedical devices which will be characterized by improved performance, conferred by the presence of such bioactive phenolic molecules and aimed at enhancing bone regeneration. Despite the encouraging results, there are some limitations to this study: First, the preliminary results obtained in terms of mRNA levels need to be confirmed and made consistent at in-depth levels through additional investigations, including the transcriptome and proteome analysis. Second, there is a need to perform in vivo studies in order to evaluate the biocompatibility, bioactivity and safety of PRPEs after a detailed characterization of their biological effects is carried out.

In conclusion, the obtained results showed that widely different PRPEs, heterogeneous molecular mixtures from Arneis and Croatina grape varieties, affect hMSC gene expression, by stimulating differentiation into the osteoblastic lineage. However, further investigations of the protein levels are needed to confirm these promising results. In view of the exploitation of these properties to enhance tissue response to dental implants and biomaterials, the present results highlighted the main challenges that will be faced by further studies, be they surface-immobilization or controlled release.

\section{Acknowledgements}

Not applicable.

\section{Funding}

No funding was received.

\section{Availability of data and materials}

The datasets used and/or analyzed during the current study are available from the corresponding author on reasonable request.

\section{Authors' contributions}

ET, GI, CC, MM and NR conceived of the study; ET, GI, CC and $\mathrm{MM}$ conceived of the methodology; ET and GI performed the formal analysis; ET, GI, CC and MM performed the investigations; MM provided the resources; ET and GI performed data curation; ET, GI and MM wrote and drafted the manuscript; CC wrote, reviewed and edited the manuscript; MM performed project administration; $\mathrm{CC}$ and $\mathrm{MM}$ acquired the funding. All authors read and approved the final manuscript.

\section{Ethics approval and consent to participate}

Cells were obtained using Institutional Review Board (IRB)-approved consent forms and protocols (BIOMED IRB-Bone marrow collection for therapeutic or non-therapeutic use-Protocol number 701-01).

\section{Patient consent for publication}

Not applicable. 


\section{Competing interests}

$\mathrm{MM}$ and $\mathrm{CC}$ own shares of the funding company Nobil Bio Ricerche srl. ET and GI are employees of Nobil Bio Ricerche srl.

\section{References}

1. Palaska I, Papathanasiou E and Theoharides TC: Use of polyphenols in periodontal inflammation. Eur J Pharmacol 720: 77-83, 2013.

2. Sankari SL, Babu NA, Rani V, Priyadharsini C and Masthan KM: Flavonoids-clinical effects and applications in dentistry: A review. J Pharm Bioallied Sci 6 (Suppl 1): S26-S29, 2014.

3. Bunte K, Hensel A and Beikler T: Polyphenols in the prevention and treatment of periodontal disease: A systematic review of in vivo, ex vivo and in vitro studies. Fitoterapia 132: 30-39, 2019.

4. Nazir MA: Prevalence of periodontal disease, its association with systemic diseases and prevention. Int J Health Sci (Qassim) 11: 72-80, 2017.

5. Özden FO, Sakallioğlu EE, Sakallioğlu U, Ayas B and Erişgin Z: Effects of grape seed extract on periodontal disease: An experimental study in rats. J Appl Oral Sci 25: 121-129, 2017.

6. Gennaro G, Claudino M, Cestari TM, Ceolin D, Germino P, Garlet GP and de Assis GF: Green tea modulates cytokine expression in the periodontium and attenuates alveolar bone resorption in type 1 diabetic rats. PLoS One 10: e0134784, 2015.

7. Tominari T, Hirata M, Matsumoto C, Inada M and Miyaura C: Polymethoxy flavonoids, nobiletin and tangeretin, prevent lipopolysaccharide-induced inflammatory bone loss in an experimental model for periodontitis. J Pharmacol Sci 119: 390-394, 2012.

8. Fernández-Rojas B and Gutiérrez-Venegas G: Flavonoids exert multiple periodontic benefits including anti-inflammatory, periodontal ligament-supporting, and alveolar bone-preserving effects. Life Sci 209: 435-454, 2018.

9. Houde V, Grenier D and Chandad F: Protective effects of grape seed proanthocyanidins against oxidative stress induced by lipopolysaccharides of periodontopathogens. J Periodontol 77: 1371-1379, 2006

10. Govindaraj J, Emmadi P, Deepalakshmi, Rajaram V, Prakash G and Puvanakrishnan R: Protective effect of proanthocyanidins on endotoxin induced experimental periodontitis in rats. Indian J Exp Biol 48: 133-142, 2010.

11. Shen CL, Wang P, Guerrieri J, Yeh JK and Wang JS: Protective effect of green tea polyphenols on bone loss in middle-aged female rats. Osteoporos Int 19: 979-990, 2008.

12. Lee JH, Jin H, Shim HE, Kim HN, Ha H and Lee ZH Epigallocatechin-3-gallate inhibits osteoclastogenesis by down-regulating c-Fos expression and suppressing the nuclear factor-kappaB signal. Mol Pharmacol 77: 17-25, 2010.

13. Nakamura H, Ukai T, Yoshimura A, Kozuka Y, Yoshioka H, Yoshinaga Y, Abe Y and Hara Y: Green tea catechin inhibits lipopolysaccharide-induced bone resorption in vivo. J Periodontal Res 45: 23-30, 2010.

14. Gómez-Florit M, Monjo M and Ramis JM: Identification of quercitrin as potential therapeutic agent for periodontal applications. J Periodontol 85: 966-974, 2014.

15. Chen JR, Lazarenko OP, Wu X, Kang J, Blackburn ML, Shankar K, Badger TM and Ronis MJ: Dietary-induced serum phenolic acids promote bone growth via p38 MAPK $/ \beta$-catenin canonical Wnt signaling. J Bone Miner Res 25: 2399-2411, 2010

16. Bu SY, Hunt TS and Smith BJ: Dried plum polyphenols attenuate the detrimental effects of TNF-alpha on osteoblast function coincident with up-regulation of Runx2, Osterix and IGF-I. J Nutr Biochem 20: 35-44, 2009.

17. Trzeciakiewicz A, Habauzit V, Mercier S, Lebecque P, Davicco MJ, Coxam V, Demigne C and Horcajada MN Hesperetin stimulates differentiation of primary rat osteoblasts involving the BMP signalling pathway. J Nutr Biochem 21: 424-431, 2010

18. Byun MR, Sung MK, Kima AR, Lee CH, Jang EJ, Jeong MG, Noh M, Hwang ES and Hong JH: (-)-Epicatechin gallate (ECG) stimulates osteoblast differentiation via Runt-related transcription factor 2 (RUNX2) and transcriptional coactivator with PDZ-binding motif (TAZ)-mediated transcriptional activation. J Biol Chem 289: 9926-9935, 2014.
19. Santiago-Mora R, Casado-Díaz A, De Castro MD and Quesada-Gómez JM: Oleuropein enhances osteoblastogenesis and inhibits adipogenesis: The effect on differentiation in stem cells derived from bone marrow. Osteoporos Int 22: 675-684, 2011.

20. Patisaul HB and Jefferson W: The pros and cons of phytoestrogens. Front Neuroendocrinol 31: 400-419, 2010.

21. Torre E: Molecular signaling mechanisms behind polyphenolinduced bone anabolism. Phytochem Rev 16: 1183-1226, 2017.

22. Torre E, Iviglia G, Cassinelli C and Morra M: Potentials of polyphenols in bone-implant devices. In: Polyphenols. Wong J (ed). IntechOpen, 2018. https://www.intechopen.com/books/polyphenols/potentials-of-polyphenols-in-bone-implant-devices. Accessed April 11, 2018.

23. Sheikh Z, Sima C and Glogauer M: Bone replacement materials and techniques used for achieving vertical alveolar bone augmentation. Materials 8: 2953-2993, 2015.

24. Rodriguez Baena RY, Rizzo S, Manzo L and Lupi SM: Nanofeatured titanium surfaces for dental implantology: Biological effects, biocompatibility, and safety.J Nanomater 2017: $18,2017$.

25. Morra M: Biomolecular modification of implant surfaces. Expert Rev Med Devices 4: 36-372, 2007.

26. Brett E, Flacco J, Blackshear C, Longaker MT and Wan DC: Biomimetics of bone implants: The regenerative road. Biores Open Access 6: 1-6, 2017.

27. Morra M, Cassinelli C, Torre E and Iviglia G: Permanent wettability of a novel, nanoengineered, clinically available, hyaluronan-coated dental implant. Clin Exp Dent Res 4: 196-205, 2018.

28. Bryers JD, Giachelli CM and Ratner BD: Engineering biomaterials to integrate and heal: The biocompatibility paradigm shifts. Biotechnol Bioeng 109: 1898-1911, 2012.

29. Insua A, Monje A, Wang HL and Miron RJ: Basis of bone metabolism around dental implants during osseointegration and peri-implant bone loss. J Biomed Mater Res A 105, 2075-2089, 2017.

30. Zhang X, Ferraris S, Prenesti E and Verné E: Surface functionalization of bioactive glasses with natural molecules of biological significance, part I: Gallic acid as model molecule. Appl Surf Sci 2013.

31. Zhang X, Ferraris S, Prenesti E and Verné E: Surface functionalization of bioactive glasses with natural molecules of biological significance, part II: Grafting of polyphenols extracted from grape skin. Appl Surf Sci 287: 341-348, 2013.

32. Córdoba A, Satué M, Gómez-Florit M, Hierro-Oliva M, Petzold C, Lyngstadaas SP, González-Martín ML, Monjo M and Ramis JM: Flavonoid-modified surfaces: Multifunctional bioactive biomaterials with osteopromotive, anti-inflammatory, and anti-fibrotic potential. Adv Healthc Mater 4: 540-549, 2015.

33. Gomez-Florit M, Pacha-Olivenza MA, Fernández-Calderón MC Córdoba A, González-Martín ML, Monjo M and Ramis JM: Quercitrin-nanocoated titanium surfaces favour gingival cells against oral bacteria. Sci Rep 6: 22444, 2016.

34. Cazzola M, Corazzari I, Prenesti E, Bertone E, Vernè E and Ferraris S: Bioactive glass coupling with natural polyphenols: Surface modification, bioactivity and anti-oxidant ability. Appl Surf Sci 367: 237-248, 2016.

35. Cazzola M, Vernè E, Cochis A, Sorrentino R, Azzimonti BC, Prenesti E, Rimondini L and Ferraris S: Bioactive glasses functionalized with polyphenols: In vitro interactions with healthy and cancerous osteoblast cells. J Mater Sci 52: 2017.

36. Cazzola M, Ferraris S, Boschetto F, Rondinella A, Marin E, Zhu W, Pezzotti G, Vernè E and Spriano S: Green tea polyphenols coupled with a bioactive titanium alloy surface: In vitro characterization of osteoinductive behavior through a KUSA A1 cell study. Int J Mol Sci 19: E2255, 2018.

37. Tsuchiya S, Sugimoto K, Kamio H, Okabe K, Kuroda K, Okido $\mathrm{M}$ and Hibi H: Kaempferol-immobilized titanium dioxide promotes formation of new bone: Effects of loading methods on bone marrow stromal cell differentiation in vivo and in vitro. Int J Nanomedicine 13: 1665-1676, 2018.

38. Iviglia G, Bollati D, Cassinelli C, Torre E and Morra M: Dreamer: An Innovative Bone Filler Paste For The Treatment Of Periodontitis. In: Dreamer: An Innovative Bone Filler Paste For The Treatment Of Periodontitis. Front. Bioeng. Biotechnol. Conference Abstract: 10th World Biomaterials Congress, 2016.

39. Kallithraka S, Garcia-Viguera C, Bridle P and Bakker J: Survey of solvents for the extraction of grape seed phenolics. Phytochem Anal 6: 265-267, 1995. 
40. Pekić B, Kovač V, Alonso E and Revilla E: Study of the extraction of proanthocyanidins from grape seeds. Food Chem 61: 201-206, 1998.

41. Shi J, Yu J, Pohorly J, Young JC, Bryan M and Wu Y: Optimization of the extraction of polyphenols from grape seed meal by aqueous ethanol solution. J Food Agric Environ 1: 42-47, 2003.

42. Neveu V, Perez-Jiménez J, Vos F, Crespy V, du Chaffaut L, Mennen L, Knox C, Eisner R, Cruz J, Wishart D and Scalbert A: Phenol-Explorer: An online comprehensive database on polyphenol contents in foods. Database (Oxford) 2010: bap024, 2010

43. Rothwell JA, Urpi-Sarda M, Boto-Ordoñez M, Knox C, Llorach R, Eisner R, Cruz J, Neveu V, Wishart D, Manach C, et al: Phenol-Explorer 2.0: A major update of the Phenol-Explorer database integrating data on polyphenol metabolism and pharmacokinetics in humans and experimental animals. Database (Oxford) 2012: bas031, 2012

44. Rothwell JA, Pérez-Jiménez J, Neveu V, Medina-Remón A, M'hiri N, García-Lobato P, Manach C, Knox C, Eisner R, Wishart DS and Scalbert A: Phenol-Explorer 3.0: A major update of the Phenol-Explorer database to incorporate data on the effects of food processing on polyphenol content. Database (Oxford) 2013: bat070, 2013.

45. Arumugam B, Balagangadharan $\mathrm{K}$ and Selvamurugan N: Syringic acid, a phenolic acid, promotes osteoblast differentiation by stimulation of Runx 2 expression and targeting of Smad7 by miR-21 in mouse mesenchymal stem cells. J Cell Commun Signal 12: 561-573, 2018.

46. Gu Q, Cai Y, Huang C, Shi Q and Yang H: Curcumin increases rat mesenchymal stem cell osteoblast differentiation but inhibits adipocyte differentiation. Pharmacogn Mag 8: 202-208, 2012.

47. Lin SY, Kang L, Wang CZ, Huang HH, Cheng TL, Huang HT, Lee MJ, Lin YS, Ho ML, Wang GJ and Chen CH: (-)-Epigallocatechin-3-gallate (EGCG) enhances osteogenic differentiation of human bone marrow mesenchymal stem cells. Molecules 23; E3221, 2018

48. Zhang J, Wu K, Xu T, Wu J, Li P, Wang $\mathrm{H}$, Wu $\mathrm{H}$ and $\mathrm{Wu} \mathrm{G}$ Epigallocatechin-3-gallate enhances the osteoblastogenic differentiation of human adipose-derived stem cells. Drug Des Devel Ther 13: 1311-1321, 2019.

49. Song LH, Pan W, Yu YH, Quarles LD, Zhou HH and Xiao ZS: Resveratrol prevents CsA inhibition of proliferation and osteoblastic differentiation of mouse bone marrow-derived mesenchymal stem cells through an ER/NO/cGMP pathway. Toxicol In Vitro 20: 915-922, 2006.

50. Dai Z, Li Y, Quarles LD, Song T, Pan W, Zhou H and Xiao Z: Resveratrol enhances proliferation and osteoblastic differentiation in human mesenchymal stem cells via ER-dependent ERK1/2 activation. Phytomedicine 14: 806-814, 2007.

51. Wittenauer J, MäcKle S, Sußmann D, Schweiggert-Weisz U and Carle R: Inhibitory effects of polyphenols from grape pomace extract on collagenase and elastase activity. Fitoterapia 101: 179-187, 2015.

52. Brand-Williams W, Cuvelier ME and Berset C: Use of a free radical method to evaluate antioxidant activity. LWT-Food Sci Technol 28: 25-30, 1995.

53. Ribéreau-Gayon P and Stonestreet E: Determination of anthocyanins in red wine. Bull Soc Chim Fr 9: 2649-2652, 1965 (In French).

54. Livak KJ and Schmittgen TD: Analysis of relative gene expression data using real-time quantitative PCR and the 2(-Delta Delta C(T)) method. Methods 25: 402-408, 2001.

55. Hammer $\varnothing$, Harper D and Ryan P: Past: Paleontological statistics software package for education and data analysis. Paleonto Electron 4: 9, 2001.

56. Santos J, Oliveira MB, Ibáñez E and Herrero M: Phenolic profile evolution of different ready-to-eat baby-leaf vegetables during storage. J Chromatogr A 1327: 118-131, 2014.

57. Dolan JW: Gradient Elution, Part V: Baseline Drift Problems. LCGC North Am 31: 538-543, 2013.

58. Snyder LR, Kirkland JJ and Dolan JW: Introduction to Modern Liquid Chromatography. 3rd Edition. Wiley, 2010.

59. Austermann K, Baecker N, Stehle P and Heer M: Putative effects of nutritive polyphenols on bone metabolism in vivo-evidence from human studies. Nutrients 11: E871, 2019.

60. Trzeciakiewicz A, Habauzit V and Horcajada MN: When nutrition interacts with osteoblast function: Molecular mechanisms of polyphenols. Nutr Res Rev 22: 68-81, 2009.

61. Kojima K, Maki K, Tofani I, Kamitani Y and Kimura M: Effects of grape seed proanthocyanidins extract on rat mandibular condyle. J Musculoskelet Neuronal Interact 4: 301-307, 2004.
62. Huang JM, Bao Y, Xiang W, Jing XZ, Guo JC, Yao XD, Wang R and Guo FJ: Icariin Regulates the Bidirectional Differentiation of Bone Marrow Mesenchymal Stem Cells through Canonical Wnt Signaling Pathway. Evid Based Complement Alternat Med 2017: 8085325, 2017.

63. Ma HP, Ming LG, Ge BF, Zhai YK, Song P, Xian CJ and Chen KM: Icariin is more potent than genistein in promoting osteoblast differentiation and mineralization in vitro. J Cell Biochem 112: 916-923, 2011.

64. Hsieh TP, Sheu SY, Sun JS, Chen MH and Liu MH: Icariin isolated from Epimedium pubescens regulates osteoblasts anabolism through BMP-2, SMAD4, and Cbfa1 expression. Phytomedicine 17: 414-423, 2010.

65. Trzeciakiewicz A,Habauzit V, Mercier S, Barron D,Urpi-SardaM, Manach C, Offord E and Horcajada MN: Molecular mechanism of hesperetin-7-O-glucuronide, the main circulating metabolite of hesperidin, involved in osteoblast differentiation. J Agric Food Chem 58: 668-675, 2010.

66. Sheng H, Zhang G, Wang X, Lee K, Yao X, Leung K, Li G and Qin L: Phytochemical molecule icariin stimulates osteogenic but inhibits adipogenic differentiation of mesenchymal stem cells. Bone 43: (Suppl 1) S42-S43, 2008.

67. Wei Q, Zhang J, Hong G, Chen Z, Deng W, He W and Chen MH: Icariin promotes osteogenic differentiation of rat bone marrow stromal cells by activating the $\mathrm{ER} \alpha-\mathrm{Wnt} / \beta$-catenin signaling pathway. Biomed Pharmacother 84: 931-939, 2016.

68. Tseng PC, Hou SM, Chen RJ, Peng HW, Hsieh CF, Kuo ML and Yen ML: Resveratrol promotes osteogenesis of human mesenchymal stem cells by upregulating RUNX2 gene expression via the SIRT1/FOXO3A axis. J Bone Miner Res 26: 2552-2563, 2011.

69. Dai J, Li Y, Zhou H, Chen J, Chen M and Xiao Z: Genistein promotion of osteogenic differentiation through BMP2/SMAD5/RUNX2 signaling. Int J Biol Sci 9: 1089-1098, 2013.

70. Yang L, Takai H, Utsunomiya T, Li X, Li Z, Wang Z, Wang S, Sasaki Y, Yamamoto $\mathrm{H}$ and Ogata Y: Kaempferol stimulates bone sialoprotein gene transcription and new bone formation. J Cell Biochem 110: 1342-1355, 2010.

71. Jung WW: Protective effect of apigenin against oxidative stress-induced damage in osteoblastic cells. Int J Mol Med 33: 1327-1334, 2014.

72. Ying X, Sun L, Chen X, Xu H, Guo X, Chen H, Hong J, Cheng S and Peng L: Silibinin promotes osteoblast differentiation of human bone marrow stromal cells via bone morphogenetic protein signaling. Eur J Pharmacol 721: 225-230, 2013.

73. Zhao L, Wang Y, Wang Z, Xu Z, Zhang Q and Yin M: Effects of dietary resveratrol on excess-iron-induced bone loss via antioxidative character. J Nutr Biochem 26: 1174-1182, 2015.

74. Kim JM, Lee SU, Kim YS, Min YK and Kim SH: Baicalein stimulates osteoblast differentiation via coordinating activation of MAP kinases and transcription factors. J Cell Biochem 104: 1906-1917, 2008

75. Liu H, Zhong L, Zhang Y, Liu X and Li J: Rutin attenuates cerebral ischemia/reperfusion injury in ovariectomized rats via estrogen receptor-mediated BDNF-TrkB and NGF-TrkA signaling. Biochem Cell Biol 96: 672-681, 2018.

76. Abdel-Naim AB, Alghamdi AA, Algandaby MM, Al-Abbasi FA, Al-Abd AM, Eid BG, Abdallah HM and El-Halawany AM: Rutin isolated from Chrozophora tinctoria enhances bone cell proliferation and ossification markers. Oxid Med Cell Longev 2018: $5106469,2018$.

77. Rassi CM, Lieberherr M, Chaumaz G, Pointillart A and Cournot G: Modulation of osteoclastogenesis in porcine bone marrow cultures by quercetin and rutin. Cell Tissue Res 319: 383-393, 2005.

78. Zhou S, Turgeman G, Harris SE, Leitman DC, Komm BS, Bodine PV and Gazit D: Estrogens activate bone morphogenetic protein-2 gene transcription in mouse mesenchymal stem cells. Mol Endocrinol 17: 56-66, 2003.

79. Hidalgo M, Sánchez-Moreno $\mathrm{C}$ and de Pascual-Teresa S: Flavonoid-flavonoid interaction and its effect on their antioxidant activity. Food Chem 121: 691-696, 2010.

80. Galanakis CM, Kotanidis A, Dianellou M and Gekas V: Phenolic content and antioxidant capacity of Cypriot wines. Czech J Food Sci 33: 126-136, 2015.

81. Gao J, Feng Z, Wang X, Zeng M, Liu J, Han S, Xu J, Chen L, Cao K, Long J, et al: SIRT3/SOD2 maintains osteoblast differentiation and bone formation by regulating mitochondrial stress. Cell Death Differ 25: 229-240, 2018 
82. Giner M, Montoya MJ, Vázquez MA, Rios MJ, Moruno R, Miranda MJ and Pérez-Cano R: Modifying RANKL/OPG mRNA expression in differentiating and growing human primary osteoblasts. Horm Metab Res 40: 869-874, 2008

83. Shakibaei M, Shayan P, Busch F, Aldinger C, Buhrmann C, Lueders $C$ and Mobasheri A: Resveratrol mediated modulation of Sirt-1/Runx2 promotes osteogenic differentiation of mesenchymal stem cells: Potential role of Runx2 deacetylation. PLoS One 7: e35712, 2012.

84. Zhang JF, Li G, Meng CL, Dong Q, Chan CY, He ML, Leung PC, Zhang YO and Kung HF: Total flavonoids of Herba Epimedii improves osteogenesis and inhibits osteoclastogenesis of human mesenchymal stem cells. Phytomedicine 16: 521-529, 2009.

85. Marini H, Minutoli L, Polito F, Bitto A, Altavilla D, Atteritano M Gaudio A, Mazzaferro S, Frisina A, Frisina N, et al: OPG and sRANKL serum concentrations in osteopenic, postmenopausal women after 2-year genistein administration. J Bone Miner Res 23: 715-720, 2008.

86. Napimoga MH, Clemente-Napimoga JT, Macedo CG, Freitas FF, Stipp RN, Pinho-Ribeiro FA, Casagrande R and Verri WA Jr: Quercetin inhibits inflammatory bone resorption in a mouse periodontitis model. J Nat Prod 76: 2316-2321, 2013.

87. Papadaki M, Rinotas V, Violitzi F, Thireou T, Panayotou G, Samiotaki M and Douni E: New insights for RANKL as a proinflammatory modulator in modeled inflammatory arthritis. Front Immunol 10: 97, 2019.

88. Boyce BF, Xiu Y, Li J, Xing L and Yao Z: NF- $\kappa$ B-mediated regulation of osteoclastogenesis. Endocrinol Metab (Seoul) 30: 35-44, 2015.

89. Bu SY, Lerner M, Stoecker BJ, Boldrin E, Brackett DJ, Lucas EA and Smith BJ: Dried plum polyphenols inhibit osteoclastogenesis by downregulating NFATc1 and inflammatory mediators. Calcif Tissue Int 82: 475-488, 2008.

90. Sheu SY, Tsai CC, Sun JS, Chen MH, Liu MH and Sun MG: Stimulatory effect of puerarin on bone formation through co-activation of nitric oxide and bone morphogenetic protein-2/mitogen-activated protein kinases pathways in mice. Chin Med J (Engl) 125: 3646-3653, 2012.

91. Mauney $\mathrm{J}$ and Volloch V: Adult human bone marrow stromal cells regulate expression of their MMPs and TIMPs in differentiation type-specific manner. Matrix Biol 29: 3-8, 2010.

92. Kobayashi T, Kishimoto J, Ge Y, Jin W, Hudson DL, Ouahes N, Ehama R, Shinkai $\mathrm{H}$ and Burgeson RE: A novel mechanism of matrix metalloproteinase-9 gene expression implies a role for keratinization. EMBO Rep 2: 604-608, 2001.
93. Philips N, Auler S, Hugo R and Gonzalez S: Beneficial regulation of matrix metalloproteinases for skin health. Enzyme Res 2011: 427285, 2011.

94. Garlet GP, Martins W Jr, Fonseca BA, Ferreira BR and Silva JS Matrix metalloproteinases, their physiological inhibitors and osteoclast factors are differentially regulated by the cytokine profile in human periodontal disease. J Clin Periodontol 31: 671-679, 2004

95. Lazăr L, Loghin A, Bud ES, Cerghizan D, Horváth E and Nagy EE: Cyclooxygenase-2 and matrix metalloproteinase-9 expressions correlate with tissue inflammation degree in periodontal disease. Rom J Morphol Embryol 56: 1441-1446, 2015.

96. Sorsa T, Mäntylä P, Tervahartiala T, Pussinen PJ, Gamonal J and Hernandez M: MMP activation in diagnostics of periodontitis and systemic inflammation. J Clin Periodontol 38: 817-819, 2011

97. Nissinen L and Kähäri VM: Matrix metalloproteinases in inflammation. Biochim Biophys Acta 1840: 2571-2580, 2014.

98. Almalki SG and Agrawal DK: Effects of matrix metalloproteinases on the fate of mesenchymal stem cells. Stem Cell Res Ther 7: 129, 2016.

99. Yun JH, Pang EK, Kim CS, Yoo YJ, Cho KS, Chai JK, Kim CK and Choi SH: Inhibitory effects of green tea polyphenol (-)-epigallocatechin gallate on the expression of matrix metalloproteinase- 9 and on the formation of osteoclasts. J Periodontal Res 39: 300-307, 2004

100. Wang D, Wang Y, Xu S, Wang F, Wang B, Han K, Sun D and $\mathrm{Li}$ L: Epigallocatechin-3-gallate protects against hydrogen peroxide-induced inhibition of osteogenic differentiation of human bone marrow-derived mesenchymal stem cells. Stem Cells Int 2016: 7532798, 2016.

101. Gómez-Florit M, Monjo M and Ramis JM: Quercitrin for periodontal regeneration: Effects on human gingival fibroblasts and mesenchymal stem cells. Sci Rep 5: 16593, 2015.

102. Vauzour D, Rodriguez-Mateos A, Corona G, Oruna-Concha MJ and Spencer JP: Polyphenols and human health: Prevention of disease and mechanisms of action. Nutrients 2: 1106-1131, 2010.

This work is licensed under a Creative Commons Attribution-NonCommercial-NoDerivatives 4.0 International (CC BY-NC-ND 4.0) License. 